\title{
Accessing the King
}

The ability to provide access to the monarch was a source of great power in pre-modern Europe and the royal household stood at the centre of networks of influence and patronage that stretched across the kingdom. Valois victory in the Hundred Years' War and the concomitant growth in French royal power led to a sharp decline in the opportunities for the subjects of the French king to seek advancement in rival royal and princely courts operating in France. By the late fifteenth century, town governments from across the kingdom (including the former Lancastrian territories of Gascony and Normandy, as well as the Burgundian lands) went to the Valois court to request the granting of their petitions. Accordingly, members of the Valois monarch's court had more power and influence than ever before, while a growth in the size of the French king's household during the later fifteenth century gave increasing numbers of people the opportunity to sell their services to urban communities. These courtiers and officials were able to use their capability to act as brokers for townspeople to strengthen their place in the increasingly pernicious and competitive environment of the French court.

The first part of this chapter examines how townspeople used gift giving at ceremonial entries to recruit brokers, who promised to ensure that the monarch and his ministers listened favourably to urban petitions. The offering of gifts to nobles and royal officers was a normal part of the system through which urban governments won tax remissions and favours. After examining the development of these networks of clientage, the chapter will move on to investigate how urban governments worked to obtain the services of a range of household staff, including guards and domestic servants. Although these individuals lacked the nobility's political influence, they had the capacity to provide to entry to royal lodgings. The chapter concludes by examining the leading role that royal women played as brokers for urban communities. Recent work on queenship has emphasised the corporate nature of pre-modern monarchies and royal women's important contribution to government. ${ }^{1}$ In sum,

1 Theresa Earenfight, The King's Other Body. Maria of Castile and the Crown of Aragon (Philadelphia, 2010); idem, 'Without the Person of the Prince: Kings, Queens, and the Idea of Monarchy in Late Medieval Europe', Gender and History 19 (2007), 1-21; Joseph F. O'Callaghan, 'The Many Roles of the Medieval Queen: Some Examples from Castile', in Theresa Earenfight, ed., Queenship and Power in Medieval and Early Modern Spain (2005), 21-32. See also the 
this chapter explores the role that ceremonial entries played in the operation of a political system that was based on favour and patronage. Access and influence were commodities that could be bought and sold - and a ceremonial entry provided a market for this transaction to occur.

\section{Brokers and Networks of Clientage}

Towns maintained brokers in the royal household to help promote urban affairs with the king. ${ }^{2}$ Mark Greengrass and Timothy Watson have shown how French urban councils worked to gain the support of the best brokers. ${ }^{3}$ Municipal governments offered substantial gifts to the powerful people who travelled with the king in order to recruit or retain their friendship. Tournai's échevins gave a gilded cup to Louis, count of Vendôme, in consideration 'of the good that he can do for the town. ${ }^{4}$ As Louis was a leading member of Charles VII's court and held great influence with the king, he was in a good position promote Tournai's affairs. Likewise, when Louis of Orléans entered Beauvais with Louis XI in January 1474, the échevins used the gift presentation to flatter the influential duke and make him aware of the problems they faced. According to

articles by Diana Pelaz Flores, Ana Rodrigues Oliveira and Isabel de Pina Balerias in: Elena Woodacre, ed., Queenship in the Mediterranean: Negotiating the Role of the Queen in the Medieval and Early Modern Eras (New York, 2013), 97-123, 125-44, 169-90.

2 For the crucial role that members of the king's household played in the petitioning process, see: Bernard Chevalier, 'The Bonnes Villes and the King's Council in Fifteenth-Century France', in J. R. L. Highfield and Robin Jeffs, eds., The Crown and Local Communities in England and France in the Fifteenth Century (Gloucester, 1981), 110-28; Philippe Contamine, 'Mécanismes du pouvoir, information, sociétés politiques', in idem, Des pouvoirs en France (1300-1500) (Paris, 1992), 16-18; Peter Lewis, 'Reflections on the role of royal clientèles in the construction of the French monarchy (mid-XIVth/end-XVth centuries)', in N. Bulst, R. Descimon and A. Guerreau, eds., L'état ou le roi. Les fondations de la modernité monarchique en France (XIV ${ }^{e}-X V I I^{e}$ siècles) (Paris, 1996), 51-67; idem, 'The Centre, The Periphery, and the Problem of Power Distribution in Later Medieval France', in Highfield and Jeffs, Crown and Local Communities, 151-68; Hélène Olland, 'La France de la fin du Moyen Age: l'État et la Nation', Médiévales 5 (1986), 89-9o; Graeme Small, 'Centre and Periphery in Late Medieval France: Tournai, 1384-1477', in Christopher Allmand, ed., War, Government and Power in Late Medieval France (Liverpool, 2000), 156-59.

3 Mark Greengrass, 'Functions and limits of political clientism in France before Cardinal Richelieu', in Bulst, Descimon and Gurreau, Fondations de la modernité monarchique, 77-78; Watson, 'Friends at Court', 281-302.

4 A. de La Grange, 'Extraits analytiques des registres des consaulx de la ville de Tournai, 1431-1476', Mémoires de la Société historique et littéraire de Tournai 23 (1893), 71. 
the civic records, 'they made him understand the poverty of the town. Without which they would have given him a gift as rich as that for the king.5 In general, municipal councils approached the most influential figures in the royal administration. When Charles IX entered Nantes in 1565 , the échevins went to the lodgings of the chancellor and the constable (two of the most powerful people in the kingdom) to offer them gifts. ${ }^{6}$ Likewise, before Mâcon's échevins brought their requests to Louis XII at his entry in June 1501, they first went to offer their services to the chancellor and Georges d'Amboise, asking in return that they recommend the municipal council to the king and seek the remittance of the gabelle levied on the town. ${ }^{7}$ Urban governments sought out royal favourites because they held considerable influence over the king's decisions. ${ }^{8}$ When Louis XI entered Rouen in 1462, for example, the town council targeted his chambellan, Jean Guaste de Montespedon, with gifts specifically because he was known to be close the king. ${ }^{9}$

In return for offering presents to dignitaries such as Montespedon, civic councils asked the recipients to persuade the king and his ministers to listen favourably to their petitions. When Louis XI entered Lyon in 1474, one of the city's leading consuls, François Buclet, was sent to find someone at court 'capable and suitable... [who had] access and entry to speak to the king'. In return for asking the king to grant the city council the right to levy a tax on the foreign currency traded in the city, the town council was prepared to pay up to five hundred écus; if the king and his ministers approved the city's request, this sum was to increase to seven hundred écus. ${ }^{10}$ Urban governments established relations with influential members of the king's entourage before bringing their requests to the monarch as the delay gave brokers time to promote urban petitions with those in power. In 1492, Orange's consuls offered gifts to Philiberta of Luxembourg's confessor and financial officers, asking them to support the requests they wanted to bring to the princess. ${ }^{11}$ Urban governments offered gifts to an array of the ruler's favourites, family members and officials in order to maximise their chances of success. When Louis XII visited

$5 \quad$ BM Beauvais Coll. Bucquet, vol. 57, p. 10.

6 AM Nantes AA 33, nos. 19, 20.

7 Bazin, 'Rois de France à Mâcon', 72.

8 For the role of favorites in decision making, see: Cédric Michon, 'Conseils, conseillers et prise de décision sous François ${ }^{\mathrm{e}}{ }^{2}$, in Roseline Claerr and Olivier Poncet, eds., La prise de décision en France (1525-1559) (Paris, 2008), 27-34; François Nawrocki, 'Le conseiller favouri, objet de la décision royale', in Claerr and Poncet, Prise de décision, $35^{-52 .}$

9 AD Seine-Maritime, AM Rouen A 8, fol. 204r.

10 Guenée and Lehoux, Entrées royales françaises, 224.

11 Aм Orange в в 8, fols. 104r, 107r. 
Dijon in 1507, the échevins awarded gifts to 'many great and noble people of this kingdom and other officers of the king... so that they have the business of this town in recommendation. ${ }^{12}$ As we shall see, it was particularly important for municipal councils to supply gifts to the king's administrative officers if they hoped to have their petitions granted.

As well as offering gifts in expectation of future support, municipal councils used royal entries to reward successful brokers for past services. At Louis XI's entry into Tournai, the échevins provided gifts to the king's favourites, Jean de Montauban and Pierre Doriole, because they had promoted the town's business with the king. ${ }^{13}$ Royal entries provided a lucrative stream of revenue for powerful men such as Doriole, who held considerable influence with the king and his council. In 1461, Tours' échevins planned to offer fifty livres to Doriole (then général des finances) at Louis XI's inaugural entry into the town. ${ }^{14}$ As Doriole's power increased when he became chancellor in 1472 so did the value of the gifts he received at a royal entry. ${ }^{15}$ If urban administrations wanted to retain the services of successful fixers, it was important to reward their achievements. Failure to offer gifts to brokers could lead them to offer their talents to other urban councils. Wealthier towns and cities hired the services of multiple brokers at court, rewarding all those who travelled with the king. When Francis I entered Amiens in 1539, the town council paid a range of people in his entourage for their efforts regarding the city's ordinances. ${ }^{16}$ The number of payments Amiens' échevins made to their fixers at Francis's entry illustrates the extent of the city's networks of influence at court. As senior officials in the royal government were often away from court on business, urban governments recruited multiple brokers in order to have friends close to the king at all times. ${ }^{17}$ Municipal councils also targeted brokers who could promote their affairs with several political authorities. When Claude of Lorraine entered Dijon in 1511, the échevins provided him with a gift 'so that he had in singular recommendation the town and its inhabitants towards the king our lord and monsieur the governor of Burgundy'18 As Claude of Lorraine's influence at court was

\footnotetext{
12 Gouvenain, Inventaire sommaire, Dijon, ii. 7.

13 La Grange, 'Entrées de souverains', 63-64.

14 AM Tours CC 35 , fol. 157 r.

15 Jean Favier, Louis XI (Paris, 2000), 299-300. For Doriole, see: Lucie Fossier, 'La fortune d'un Rochelais du XVe siècle: Pierre Doriole', Revue de la Saintogne et de l'Aunis 3 (1977), 49-66; P. S. Lewis, 'The Centre, the Periphery and the Problem of Power Distribution in Later Medieval France', in Highfield and Jeffs, Crown and Local Communities in England, 43-44.

16 Aм Amiens в в 23, fol. 3v.

17 Watson, 'Friends at Court', 295.

18 Gouvenain, Inventaire sommaire, Dijon, ii. 27.
} 
growing in the 1510s, he was in a good position to promote Dijon's affairs with both Louis XII and the governor of Burgundy, Louis de La Trémouille. The expansion of provincial governors' powers in the sixteenth century led urban governments to seek influence with these individuals, especially as governors had the authority to make some grants without having to consult the king (see chapter four). Claude of Lorraine was a valuable asset for Dijon's rulers because his ascendancy at court promised to work to their advantage. Accordingly, the échevins offered Claude a large gift both to reward past success and retain his future service.

Royal entries gave urban administrations opportunities to construct and consolidate networks of clientage. The brokers recruited by municipal leaders helped to ensure that the king and his ministers received urban petitions favourably. On the evening of Louis XI's entry into Brive-la-Gailliarde in June 1463, the municipal council gave Charles of France, the king's brother, a gift of salmon. As they offered the fish to the duke, the consuls described 'the poverty and needs of the said town', asking Charles to promote their affairs to the king, which he agreed to do. Brive's consuls waited until the duke had spoken to Louis before presenting their requests. ${ }^{19}$ Before Charles went into rebellion against his brother during the War of the Public Weal in 1465, he was a key broker for urban communities. When Louis XI entered Tournai in 1463, the échevins gave Charles a silver cup containing 200 écus in return for the efforts he had taken on the city's behalf. ${ }^{20}$ While urban communities situated close to the centres of Valois power were able to cultivate relations with members of the king's family over a long period of time, towns such as Brive-la-Gaillard or Tournai lacked opportunities to do so because they were rarely visited by French monarchs. ${ }^{21}$ For these civic administrations, a royal entry provided a good moment to win friends at court.

The rulers of towns that were not to be visited during a royal progress could send delegations to attend neighbouring entries to try and make contact with the king. ${ }^{22}$ Orange's consuls sent delegations to attend royal entries at Caderousse, Lyon and Tarascon in order to submit their requests to the French

\footnotetext{
19 Guenée and Lehoux, Entrées royales françaises, 182.

20 Guenée and Lehoux, Entrées royales françaises, 198.

21 Rivaud, Villes et le roi, 203.

22 Other authorities could also send representatives to attend entries. For example, the entry of the Dauphin Louis into Compiègne in July 1443 was attended by representatives from surrounding abbeys, as well as from neighbouring towns: AM Compiègne CC 16 fol. 13v; Marcel Thibault, La jeunesse de Louis XI, 1423-1445 (Paris, 1907), 245.
} 
king. ${ }^{23}$ Although some urban delegations found it difficult to access to the king when he entered a neighbouring town, French monarchs were receptive to receiving petitions from those places they did not intend to visit as these urban governments would otherwise lack the opportunity to offer him their requests. Of course, these municipal delegations first had to gain contact with the king, which (as we saw in the previous chapter) could be difficult. Nonetheless, those delegations that were able to negotiate or cajole their way to an audience with the king could win substantial grants. The delegation Pont-Audemer sent to attend Charles viI's entry into Louviers in September 1449 secured an exemption from the taille for six years. ${ }^{24}$ Charles was then campaigning in Normandy to return the duchy his obedience after thirty years of Lancastrian rule. While Charles did not intend to enter Pont-Audemer, its leaders were able to re-construct their relations with him (which were entirely curtailed with the imposition of Henry v's rule in 1419) at his entry into Louviers. The presence of Pont-Audemer's delegation at Charles's entry into Louviers was also a mark of the Valois monarch's success because it represented the further contraction of Lancastrian Normandy. As it was clear to Pont-Audemer's administration that the Dual Monarchy was on the point of collapse, they travelled to Louviers to offer their submission to Charles before they were besieged. By voluntarily capitulating to the Valois king rather than being taken by force, Pont-Audemer expected to secure new rights from the king. Although many Norman towns had prospered under the Dual Monarchy, Pont-Audemer's councillors justified their application for remission from the taille by claiming that the town had suffered under Lancastrian rule. From Charles's perspective, he needed to win local support if he hoped to make his rule in Normandy permanent - and the issuing of lucrative grants to urban leaders was one way to achieve this.

For urban governments from more remote parts of the kingdom, the presence of the royal court in their region provided them with an opportunity to ask the monarch to intervene in local disputes in their favour. Delegates from the small town of Puy-Saint-André travelled to Louis XII's entry at Embrun in June 1502 to seek the confirmation of their rights over the neighbouring mountain of Les Combes. While John, dauphin of Auvergne, had granted PuySaint-André these rights in perpetuity in 1311, local rivals were threatening the

23 Ам Orange в в 5, fols. 86r (Tarascon), 103r (Lyon); в в 11, fol. 129r (Caderousse). Orange sent twelve leading townsmen to bring their requests to Francis I when he entered Caderousse in 1536: Aм Orange вв 12, fol. 253r.

24 T. Bonnin, Cartulaire de Louviers. Documents historiques originaux du Xe au XVIII e siècle, 5 vols (Evreux, 1883), ii. 241-44. 
town's claim to the mountain in the early sixteenth century. ${ }^{25}$ It was important for small towns such as Puy-Saint-André (lying in regions rarely visited by the court and far from the centres of royal power) to obtain contact with the king during a progress as their limited financial resources meant they could not easily send delegations to court, let alone afford keep them there. It was particularly important for smaller towns to gain access to the king at an entry when they were in conflict with more powerful regional political authorities. When Orange's consuls learnt that Charles viII was to enter Lyon in 1490, they sent a delegation to seek the king's confirmation of the market his ancestors had granted to the town. This issue was of crucial importance for the consuls as they were in conflict with both the neighbouring town of Carpentras and the Parlement of Dauphiné over the right to the market. ${ }^{26}$ In short, a royal entry provided smaller urban communities, such as Orange or Puy-Saint-André, with an opportunity to gain access to the king and have him intercede in local quarrels on their behalf.

The onset of the Italian Wars in 1494 led French kings to make extended visits to Lyon (indeed, the city became a centre of monarchy under Charles VIII and Louis XII ). ${ }^{27}$ During Lyon's time as de facto capital of the kingdom, neighbouring towns regularly sent delegations to attend its royal entries and offer petitions to the king. When Louis XII returned from campaign in Italy the mayor of Dijon travelled two hundred kilometres to greet him at Lyon. ${ }^{28}$ Despite being a base for the Valois monarchy, Lyon could not be certain of a royal entry. As part of their preparations for Henry II's reception in 1548, the consuls devised a contingency plan to offer their requests to the king: should Henry II cross into Piedmont without entering the city, the city council planned to ask the governor of the Lyonnais (Jean d'Albon de Saint André) to bring its petitions to the monarch. ${ }^{29}$ Given the political and economic importance of ceremonial entries for urban communities, the cancellation of a royal visit was detrimental for townspeople, especially if they had already paid for the plays and decorations. When Francis I cancelled his planned entry into Toulouse in March 1526, the municipal council sent a delegation to the king

25 P. Guillaume, 'Louis XI à Embrun', Bulletin de la Société d'études des Hautes-Alpes (1882), $3^{2-} 35$.

26 Aм Orange вв 8, fols. 57r, 92r.

27 L. Bourgeois, Quand la cour vivait à Lyon (1494-1551) (Brignais, 2004); Brink, 'Louise de Savoie', 23; Dauphant, Royaume, 287, 301; Dorothy Moulton Mayer, The Great Regent: Louise of Savoy, 1476-1531 (London, 1966), 197.

28 Gouvenain, Inventaire sommaire, Dijon, i. 49.

29 Ам Lyon вв 67, fol. $230 \mathrm{ov}$ 
to seek the confirmation of its privileges. Despite having had these privileges confirmed at court at the beginning of the reigns of Charles VIII (1483) and Louis XII (1498), Toulouse does not appear to have had its liberties confirmed on Francis I's ascension to the throne, which may explain the eagerness to have Francis ratify them in $1526 .{ }^{30}$ As this was to have been Francis's first visit to the city, the consuls had not yet had their liberties and franchises authorised by the monarch. ${ }^{31}$ Furthermore, Francis had just been released from captivity in Madrid, during which time his mother, Louise, acted as regent. As soon as Toulouse's consuls learnt of Francis I's capture at Pavia in 1525, they sent a delegation to Louise of Savoy to have her confirm the city's privileges because she was the effective ruler of the kingdom. ${ }^{32}$ In order to guarantee their privileges, towns took great efforts to ensure they had their rights reconfirmed following any change in rule, whether as a consequence of the death of a monarch or the end of a regency. Hence, Toulouse's municipal council wanted to guarantee its privileges as soon as Francis I had returned to France. Nonetheless, the municipal council had to wait until the king entered the city in 1533 to offer him their petitions for new liberties. ${ }^{33}$

Although the cancellation of a royal entry harmed urban finances due to the costs of staging the entry, losing the opportunity to offer gifts to the king and petition him for new liberties was of much greater concern to civic governments. In these circumstances, town councils could transport an entry's giftgiving element directly to the ruler. When Charlotte of Savoy failed to enter Tours in 1461, the civic leaders sent a delegation to the royal palace in Amboise to offer their gifts to the new queen of France. ${ }^{34}$ Tours' location at the centre of Valois power meant that its rulers had regular access to the royal court, which was based around the Loire during the fifteenth century. In contrast, towns and cities lying far from the Valois heartlands did not enjoy the same ease of contact with the court. Furthermore, it was dangerous to transport valuable gifts over long distances, especially by road, due widespread banditry. Although the rulers of Tours could sail the short distance upriver to Amboise to bring

30 See, for example: AM Toulouse AA 3/228/288 (Charles VIII); AA 5/403 (Louis XII). Furthermore, they had their privileges confirmed at the beginning of Henry II's reign in 1547: AA 8/1.

31 AM Toulouse BB 9, fols. 3or-34v.

32 Ам Toulouse вв 9, fol. 8v; Brink, 'Louise de Savoie', 18.

33 AM Toulouse AA 5/97.

34 Rivaud, 'Entrées à Tours', 159-61. 
their gifts to Charlotte of Savoy, this option was not available to most urban administrations. ${ }^{35}$

Sedentary courts, such as that based around Tours, attracted municipal delegations, which competed against each other to persuade the king and his officers to favour their requests over all others. However, many towns could not afford to send a delegation to try and gain access to king, even when the court was in their vicinity. When Charles viII toured the centre-west of France in 1487 , Bergerac (which was not visited on this progress) decided to dispatch agents to attend the king's entry into the neighbouring city of Bordeaux. The consuls hoped to gain access to Charles and offer him a petition seeking exemption from the taille. ${ }^{36}$ As a small town, Bergerac had limited finances; indeed, its municipal council even struggled to raise sufficient funds to send its representatives the short distance to Bordeaux. Although one of Bergerac's wealthiest consuls agreed to fund the delegation, his offer came too late: the king had already departed from Bordeaux and the consuls did not have the funds to follow the court over a longer distance. ${ }^{37}$ Unable to speak to the king or his council, Bergerac's requests remained unheard. Even when urban governments could afford to send representatives to attend entries at neighbouring towns, they could not be sure of gaining access to the king as they were dependent on the good will of their neighbours. Amiens' échevins exploited their good relations with Abbeville's rulers to gain a place at Henry vi's entry into the town in July 1430, which enabled them to recommend the city to the Lancastrian monarch. ${ }^{38}$ Yet obtaining this level of support could be difficult because towns offered the monarch requests for liberties that were often detrimental to their neighbours. ${ }^{39}$ As such, urban administrations preferred to access the monarch in their own town, where they could control the environment and restrict the involvement of rivals. ${ }^{40}$ Having control of the wider context of a royal visit was important for town councils because (as well as providing access to the monarch) a ceremonial entry allowed municipal councils to meet those key

\footnotetext{
35 Rivaud, 'Entrées à Tours', 159-61.

36 Charrier, Jurades de Bergerac, i. 21.

37 Charrier, Jurades de Bergerac, i. 24-25.

38 AM Amiens B B 4, fol. 2v; CC 24, fol. 39v; Ledieu, Inventaire sommaire, Abbeville, 64; Ernst Prarond, Histoire d'Abbeville: Abbeville aux temps de Charles VII, des ducs de Bourgogne, maitres du Ponthieu, de Louis XI, 1462-1483 (Paris, 1899), 15-16. For the wider context of this entry see: Murphy, 'Amiens', 153-54.

39 Gisela Naegle, 'Vérités contradictoires et réalités constitutionnelles. La ville et le roi en France à la fin du Moyen Age', Revue historique 632 (2004), 730, 732.

$40 \quad$ Rivaud, Villes et le roi, 99.
} 
officials in the royal administration who were in a good position to ensure that urban elites obtained new rights, particularly the chancellor.

\section{The Chancellor}

The chancellor was one of the most important royal officers in France and he held wide-ranging powers that extended across the kingdom. He had regular and privileged access to the king and was one of the few members of the royal entourage permitted to reside in the monarch's residence during a progress. In addition to his considerable judicial powers (which included drafting royal edicts), the chancellor played a key role in fiscal affairs. ${ }^{41}$ Furthermore, chancellors offered continuity between reigns (Francis I's chancellor, François Olivier, was one of the few members of the royal council to survive the transition to Henry II's rule in 1547$).{ }^{42}$ Gaining entry to the king's council was crucial for townspeople as the members of the council examined urban requests. For instance, when Charles v entered Tournai in 1368, the town council went to his lodgings in the abbey of Saint-Martin 'and made numerous requests to the king, in the presence of his council'.43 Whereas it was customary for kings to receive petitions in person on Friday mornings during the fourteenth century, the monarch stopped attending this session in person (except on Good Friday) during the fifteenth century, instead delegating the responsibility to the chancellor. ${ }^{44}$ Furthermore, because the king was normally absent from the afternoon sitting of the royal council, the chancellor also presided over this meeting. ${ }^{45}$ By the late fifteenth century, the afternoon session of the royal council (known as the conseil privé) had grown very powerful, particularly because it evaluated all the petitions handed to the king. When Poitiers' consuls brought their requests to Charles viII following his entry into the city in 1487, the chancellor instructed them to prepare a written document setting out the specifics of their petitions so that the royal council could examine them. ${ }^{46}$

41 Knecht, Renaissance France, 14-15; Potter, Nation State, 137. For late medieval chancellors, see also: Guido Castelnuovo and Olivier Mattéoni, eds., Chancelleries et chanceliers des princes à la fin du Moyen Âge. De part et d'autre des Alpes (II) (Charenton, 2011).

42 Michon, 'Conseils et conseillers', 48-52. For Olivier's career see, Cédric Michon, 'La valse des gardes des sceaux', in Michon, Conseillers de François I ${ }^{e r}$, 570-73.

43 Smet, 'Chronique des Pays-Bas', 245.

44 Chevalier, 'King's Council', 112.

45 Chevalier, 'King's Council', 112; Ferdinand Lot and Robert Fawtier, Histoire des institutions françaises au moyen age, 3 vols (1957-62), ii. 83 .

46 Rivaud, Entrées princières, 123-24. 
After scrutinising Poitiers' requests, the royal council approved them all. The chancellor then directed the town council to bring copies of the grants to be registered by the généraux des finances ${ }^{47}$ Given the chancellor's central role in the granting of urban liberties, it was important for municipal governments to win his favour. When planning the inaugural entries of Louis XI and Charlotte of Savoy in 1461, Tours' échevins ruled that the chancellor was to be given a gift both in recognition of his previous efforts on behalf of the town and to ensure that he 'seals and expedites the privileges of the town' 48 Chancellors also advertised their ability to obtain liberties for towns. In the days leading up to Francis I's entry into Dijon in 1521, Antoine Duprat wrote to the échevins reminding them of his power with regards to the granting of liberties at the king's entry, thus tacitly encouraging them to provide him with gifts. ${ }^{49}$ As well as being able to recommend urban petitions to the royal council, the chancellor controlled the ratification of royal grants. He held the great seal (which legitimised royal acts) and could refuse to issue any grants he considered prejudicial to the Crown. ${ }^{50}$

Municipal governments used gift gifting at entries to win the chancellor's support for their petitions. When Francis I entered Dijon in 1541, the échevins gifted expensive wine to the chancellor, Guillaume Poyet, 'so that he had the town in recommendation. ${ }^{51}$ The gifts offered to the chancellor were second only to those of the king - and chancellors were amongst the privileged few who received gifts of silverware. When Louis XI entered Rouen in 1462, for example, the town council gave ten silver cups to the chancellor, Pierre de Morvilliers. ${ }^{52}$ Failure to provide the chancellor with a suitable gift could lead to the failure of urban petitions. In 1548, Lyon's civic council made a series of ill-judged decisions regarding gift giving at Henry II's entry. In addition to offering unsuitable items of silverware to the king and queen, the consuls failed to provide the chancellor, François Olivier, with a gift. At first glance, Lyon's negligence seems unusual, as the consuls had planned to offer a gift to the chancellor at Henry's entry; indeed, the municipal deliberations state

47 Rivaud, 'Accueil des souverains', 285.

48 Aм Tours в в 10, fol. 347 r.

49 J. G. Garnier, ed., Correspondance de Mairie de Dijon extraite des archives de cette ville, 3 vols (Dijon, 1864), i. 293-94.

50 For the chancellor's seal see: Bernard Barbiche, 'De la commission à l'office de la Couronne: les gardes des sceaux de France du XVI ${ }^{\mathrm{e}}$ au XVIII ${ }^{\mathrm{e}}$ siècle', Bibliothèque de l'École des Chartes 151 (1993), 359-90.

$5^{1}$ Gouvenain, Inventaire sommaire, Dijon, ii. 7 .

$5^{2}$ AD Seine-Maritime, Am Rouen A 8, fol. 204r. 
that it was essential they did so as they had not provided Olivier with a gift on his appointment to the office three years earlier. ${ }^{53}$ However, a closer investigation of the negotiations that took place between the chancellor and city in advance of Henry II's visit to Lyon reveals that the consuls may have deliberately chosen not to offer Olivier gifts because he had failed to act as an effective broker for the city. Despite his senior role in the kingdom's administration, Olivier had been unable to persuade the royal council to pre-approve Lyon's petition for tax exemption, which the consuls intended to bring to Henry II at his entry. French urban governments customarily provided gifts to chancellors at royal entries to reward their successful promotion of municipal affairs at court. When Charles vi entered Amiens in 1414, the échevins gave the chancellor, Henri de Marle, an expensive jewel in return for the efforts he had taken on their behalf. ${ }^{54}$ Likewise, when Eleanor of Austria entered Abbeville in December 1531, the municipal council gifted wine to the chancellor, Antoine Duprat, 'in consideration of the great pleasures' he had made for the town at court. ${ }^{55}$ As François Olivier had failed to secure grants for Lyon in 1548, the consuls may not have considered themselves bound to offer him a gift at Henry II's entry. If so, their actions were ill considered because the consuls left the chancellor with no incentive to promote their interests at court in the future.

As the subsequent actions of Lyon's municipal council make clear, urban governments provided gifts to royal officials in return for favours. Lyon sent a delegation sent to court in January 1549 to persist in its endeavour to obtain tax exemption. As part of their efforts, the consuls instructed the delegates to offer a gift to the chancellor to 'repair the fault which was done in not having made him a gift at the entry of the king and queen'. ${ }^{56}$ By the time the delegation left the city, Lyon's situation had grown desperate: not only had all its efforts to obtain relief from the war tax failed, the Crown had also threatened the city leaders with imprisonment. ${ }^{57}$ Despite obtaining the right to levy a wine tax during Henry II's visit, the consuls were unable to have this grant ratified. 58 While the chancellor failed to persuade the royal council to grant Lyon

53 Ам Lyon в в 67, fol. 245v.

54 Aм Amiens Bв 2, fol. 46r.

55 Ledieu, 'Élénore d'Autriche à Abbeville', 63.

56 Aм Lyon Bв 68, fol. 299r. Paris's échevins also tried to win the support of the chancellor's services in order to gain exemption from this tax: Godefroy, Cérémonial françois, i. $299-300$.

57 Indeed, on 20 March 1549 forty-three members of the city elite were arrested and imprisoned: AM Lyon Bв 68, fols. 324v-326r.

58 Ам Lyon в в 67 , fol. 281v, в в 68 , fol. 324 v. 
immunity from the war contribution, he was in a key position to ensure that the octroi on wine was registered. As such, the consuls used gift giving in an attempt to secure his services and they gave Olivier an item of silverware valued at between $5^{-600}$ livres, which was the same value as the gift they offered Henry II at his inaugural entry four months earlier. ${ }^{59}$ Other municipal councils were quicker to rectify oversights in providing the chancellor with gifts. When Francis I entered Pont-Audemer in July 1540, the town council also neglected to offer a present to the chancellor, Guillaume Poyet. The échevins regretted this error, particularly as they considered Poyet to be 'amongst the notable people who could help the inhabitants of the town'. As soon as the councillors realised their mistake, they sent a delegation to Vatteville to offer gifts to the chancellor, aware of his power to obtain new liberties for the town. ${ }^{60}$

There was a fine line between legitimate gift giving (which was made in payment for services) and bribery, particularly from the 1540 s when there was a growing uncertainty amongst senior royal officials, especially the chancellor, about what types of gifts were appropriate. In the mid-sixteenth century, the Crown placed restrictions on the value and types of gifts that royal officials were permitted to receive; indeed, expensive gifts had to be approved by the king. ${ }^{61}$ When Henry II entered Rouen in 1550, the échevins offered François Olivier gifts of such value that he spoke to the king before accepting them. ${ }^{62}$ When Olivier's predecessor, Guillaume Poyet, refused to accept a golden cup from the consuls of Lyon in 1541, the city paid his close associates to persuade the chancellor to receive their gift, thus binding him to repay the favour. ${ }^{63}$ Moreover, the manner in which gifts were presented was crucial: legitimate gifts were made openly and with an audience, whereas bribes were given in secret. ${ }^{64}$

59 Ам Lyon в в 68, fol. 299r.

60 Pont-Audemer's financial accounts, given in Canel, Histoire de Pont-Audemer, ii. 35. For Poyet as chancellor, see: Marie Houllemare, 'Guillaume Poyet (v. 1473-1548)', in Michon, Conseillers de François I ${ }^{\text {er }}$, 370-76.

61 Edict du Roy prohibitif à tous Gouverneurs, leurs Lieutenants, Presidens, Tresoriers, Generaulx, et autres officiers Royaulx, de prendre n'exiger du peuple deniers n'autres presens, sans la permission expresse dudict seigneur Roy (Paris, 1560). See also: Davis, The Gift, 144-45; idem, Fiction in the Archives: Pardon Tales and their Tellers in Sixteenth-Century France (Stanford, 1987), 10, 153; Hélène Michaud, La grande chancellerie et les écritures royales au XVIs siècle (1515-1589) (Paris, 1967), 113, 295.

62 AD Seine-Maritime, Am Rouen A 16, fol. 116r.

63 Davis, The Gift, 144.

64 Algazi, 'Doing Things with Gifts', 84-85; Braake, 'Brokers in the Cities', 169-70; Davis, The Gift, 67-84; Sharon Kettering, 'Gift-Giving and Patronage in Early Modern France', French History 2 (1988), 147-51. 
The gifts that towns offered to chancellors at royal entries were not made in public. When Louis XI entered Tours the échevins decided to offer their presents to the chancellor 'at his lodging... so that that he always recommends the people and business [of the town] towards the king' ${ }^{65}$ Given the concerns surrounding the legality of gifts, François Olivier wanted to gain Henry II's approval that Rouen's expensive present (which was made in his residence and without a wider audience) was a legitimate gift, rather than a bribe.

The efforts the Crown took in the middle decades of the sixteenth century to reform gift giving formed a part of the monarchy's attempt to overhaul the judicial system. Yet, despite the apparent sincerity of these efforts to clamp down on corruption, the distinction between legitimate gift giving (made in return for services) and bribes remained uncertain. ${ }^{66}$ In a shrewd move, some municipal councils offered their presents to the chancellor's wife, thus avoiding any negative connotations with gift giving. When Louis XI entered Tournai, the town council gave Philippe de Morvilliers' wife two silver pots in consideration of the efforts her husband the chancellor had taken on behalf of the town. ${ }^{67}$ Likewise, at Louis XII's entry into Troyes in 1510 the cathedral chapter (which was trying to obtain new liberties from the king) gave the chancellor a gift through the hands of his wife. ${ }^{68}$ Furthermore, the offering of gifts to female relatives of powerful men shows an awareness of practical politics: municipal councils hoped these women would persuade their husbands, brothers and fathers to act in the interests of the town. When Louis XI entered Lyon in 1476, the échevins offered ten aulnes of velvet cloth to Georgette de Montchenu, wife of Ymbert de Batarnay, lord of Bouchage, 'in compensation for the services and pleasures that the said lord of Bouchange, her husband, has made and can make for the town'.69 Many people sought Batarnay's services because he was an influential broker and one of Louis XI's most trusted supporters. ${ }^{70}$ As well as being one of the king's favourites, Bouchage came from a powerful family,

65 Aм Tours B B 10, fol. 347 r.

66 Davis, The Gift, 146-49.

67 A. de La Grange, 'Extraits des comptes généraux de Tournai, 1463', Mémoires de la Société littéraire et historique de Tournai 19 (1885), 62.

68 Léon Pigeotte, Étude sur les travaux d'achèvement de la cathédrale de Troyes 1450 à 1630 (Paris, 1870), 95.

69 Lehoux and Guenée, Entrées royales françaises, 221. Georgette later asked for fifty écus instead of the cloth, possibly as this was of more value to her husband: Boulieu, 'Louis XI à Lyon', 411.

Lewis, 'Role of Royal Clientèles', 63-64; Bernard de Mandrot, Ymbert de Batarnay: seigneur de Bouchage, conseiller des rois Louis XI, Charles VIII, Louis XII et François I ${ }^{\text {r }}$, 1438-1523 (Paris, 1886), 4-11; Potter, Nation State, 58-59, 140. 
which held extensive lands in the Dauphiné. ${ }^{11}$ As this territory bordered Lyon, Bouchage was in a good position to help the city's commercial interests in the region. By offering gifts to the wives of influential men, urban administrations sought to circumvent both the restrictions and the uncertainties around gift giving, and to oblige these powerful individuals to help them.

\section{Royal Secretaries and the Ratification of Urban Grants}

The capacity to grant petitions was a crucial attribute of pre-modern kingship. As a potent mark of power and legitimacy, it boosted the monarch's authority. It is striking to note that French kings did not refuse requests brought to them at a royal entry. Occasionally, the king would inform a municipal council that he was delaying his approval for a grant, though such instance were rare and, crucially, he did not reject the petition. ${ }^{72}$ It was important that the king showed his subjects he was a benevolent ruler who used his power for their good. By approving petitions, the monarch demonstrated that he possessed to the wealth, authority and legitimacy necessary to dispense grants. It was damaging to the character of the monarchy to refuse a petition, as it could imply that the king lacked the power to grant it. This issue was of fundamental importance to the French Crown because the Valois monarchy's legitimacy to rule was contested regularly between the reigns of Philip VI and Henry III. Nonetheless, having the king's verbal approval of a petition at an entry was not sufficient enough for it to be granted. It was only the beginning of a complex process of negotiation between royal and urban officials in which the king's secretaries played a crucial role.

The royal secretaries developed out of the clerks of the Grand Chancellerie, who were employed to perform a range of general administrative tasks

71 M. Harsgor, Un très petit nombre: des oligarchies dans l'histoire de l'Occident (Paris, 1994), 168-69.

72 For example, the Catholic leaders of Nîmes petitioned Charles IX at his entry in 1564 for the right to form a consulate. This was a complex case, as the Catholic elite was trying to re-impose its rule over the town's Protestant population. While it was beneficial for Charles to have the town ruled by Catholics, this petition had ramifications for the power and authority of the archbishop of Narbonne, whose jurisdiction extended over the town. The situation was particularly delicate as the see of Narbonne was under the authority of Ippolito II d'Este, who had close links with the Valois monarchy. As Charles only visited Nîmes briefly, he promised to look more closely at the requests when he reached Montpellier: AM Nîmes LL 10. 
including the drafting of royal letters. ${ }^{73}$ In 1372 , Charles v raised the profile of those clerks who had the right to sign documents concerning royal finances and they became known as the secrétaires des finances. ${ }^{74}$ They were powerful members of the royal household and had constant access to the king. ${ }^{75}$ Unlike the higher nobility, who were often called away from court on military or administrative matters, the secretaries accompanied the king wherever he travelled. Given the remit of their work, it was essential that the secretaries were close to the king at all times, day and night, whether he was in a royal palace or on a hunt, progress or campaign. ${ }^{76}$ While the royal secretaries began their rise to prominence in the late fourteenth century, they did not become crucial to the granting of urban petitions until the mid-fifteenth century. From the reign of Louis XI, royal secretaries were indispensable to the granting of urban liberties because they evaluated the king's concessions; indeed, the royal secretaries had to counter-sign all grants issued by the king for them to be legal. ${ }^{77}$ When Louis XI wanted to issue new liberties to Amiens, he had a copy of this grant authorised by his secretary, Gilles Le Flameng. ${ }^{78}$ As we shall see, the emergence of the royal secretaries was part of a process whereby from the mid-fifteenth century political power was being concentrated in the hands of a small group of officials who sat on the king's council. ${ }^{9}$

Royal secretaries became fundamental to ceremonial entries during the second half of the fifteenth century as a consequence of their vital role in both the confirmation of municipal rights and the granting of new liberties. They even travelled with the people the king sent to make entries on his behalf. Charles viI's secretaries were part of the entourage of Jean, count of Dunois, who entered the conquered city of Bordeaux as the Valois monarch's proxy in

73 N. M. Sutherland, The French Secretaries of State in the Age of Catherine de Medici (London,

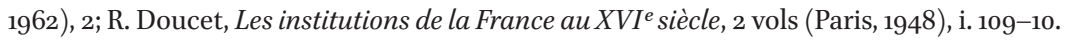

74 Marie-Bernadette Brugière, Henri Gilles and Germain Sicard, Introduction à l'histoire des institutions françaises des origines à 1792 (Toulouse, 1983), 129; Octave Morel, La Grande Chancellerie royale et l'expédition des lettres royaux de l'avènement de Philippe de Valois à la fin du XIV siècle (Paris, 1900), 69; J. H. Shennan, Government and Society in France 1461-1661 (Birkenhead, 1969), 40. There were six sécretaires des finances by 1400: Michon, 'Conseils et conseillers', $5^{2}$.

75 André Lapeyre and Remy Scheurer, Les notaires et sécrétaires du roi sous les règnes de Louis XI, Charles VIII et Louis XII: notices personnelles et généalogies, 2 vols (Paris, 1978), i. xxvi.

76 Sutherland, French Secretaries of State, 16.

77 Sutherland, French Secretaries of State, 10.

78 Favier, Louis XI, 270.

79 Potter, Nation State, 288. 
$1451 .{ }^{80}$ As Bordeaux had been under English rule for three centuries, the French king needed his legal experts to assess the privileges he had sent Dunois to confirm on his behalf. The secretaries' responsibility for the granting of liberties arose from the Crown's need to develop a system whereby experts could consider the full implications of the petitions it received. In other words, the secretaries made sure that grants of rights and liberties were not unduly detrimental to the Crown. Furthermore, as royal secretaries were recruited from provincial royal and municipal administrations, they were experts at analysing urban petitions.

As soon as municipal councils received the king's verbal confirmation of their petitions at an entry, they directed their lawyers to prepare written copies of these requests. Whereas the petitions urban governments made to the monarch were given without elaboration, the written copies handed to the king's secretaries set out both the specific elements of each grant and the reasons why they were seeking the grant. For example, Mâcon's échevins petitioned Louis XII for exemption from the gabelle at his entry in 1501. As soon as Louis approved their request, the échevins drew up a letter explaining to his secretaries that they needed this tax remission due to the decline of the fortunes of the town and its merchants as a result of 'the exactions, oppressions and abuses' caused by the tax farmers who were sent to collect the gabelle ('fermiers d'icelles gabelles'). ${ }^{81}$ In the case of a royal minority, written copies of the petitions were also sent to the regent, who presided over the royal council. When the young Charles viII made his inaugural entry into Reims in 1484, the municipal council's requests were sent to Anne of Beaujeu. ${ }^{82}$ The procedures the Crown developed to issue grants at entries permitted the monarch to sustain the appearance a ruler who was open to receive the petitions of all his subjects. As we saw, French monarchs stood in the shadow of Louis IX, whose reign was looked on as a golden age because of his efforts to allow his subjects access to the king. As well as being open to receive petitions, the king had to be able to grant any request his subjects put to him. In theory, no temporal

8o Godefroy, Cérémonial françois, i. 1004-5. For Charles vin's secretaries, see: Roger G. Little, The Parlement of Poitiers: War, Government and Politics in France, 1418-1436 (London, 1984), 45-53; G. Tessier and G. Ouy, 'Notaires et secrétaires du roi dans la première moitié du $\mathrm{XV}^{\mathrm{e}}$ siècle d'après un document inédit', Bulletin philologique et historique du Comité des Travaux historiques et scientifiques 2 (1963), 861-90.

81 AM Mâcon вв 22, fols. 39r-41v; Bazin, 'Rois de France à Mâcon', 72-73; B. Rameau, 'Entrée de Louis XII à Mâcon', Annales de l'Académie de Mâcon. Société des arts, sciences, belleslettres et agriculture de Saône-et-Loire 8 (1901), 415.

82 Bartholomé, 'Mémoires de Jean Foulquart', 147. 
request lay beyond his power to grant; in practice, it was not feasible to grant all petitions, especially those that went against law or custom. As part of his efforts to remove corruption from the petitioning process, Henry III sought to strip the royal secretaries of their power to approve or decline royal grants. In response to the king's actions, Nicolas de Neufville, his leading secrétaire d'Etat, justified this power. He explained to Henry that because it was customary for French kings to approve all petitions, his ancestors had granted the secretaries the power to block any unlawful requests. ${ }^{83}$ Hence, the secretaries ensured that good government prevailed over corruption and bribery.

Despite the monarch's appearance of accessibility, the real business of government took place behind the scenes and without the king's involvement. The monarch was the channel through which civic administrations delivered their pleas and ultimately it was the royal secretaries who decided whether or not to approve urban petitions. Royal secretaries held considerable administrative power and they declined any request authorised by the king they considered to be unduly detrimental to the rights and prerogatives Crown. While a Parisian delegation obtained Louis XI's approval for substantial tax remissions at his entry into Poitiers in 1465 , the grant was never implemented because the king's officials did not approve it. ${ }^{84}$ This was an effective system for the French monarchy as the secretaries formed a barrier between the king and his subjects. At times, the king instructed his royal council not to accept requests rather than decline them in person. For example, during his visit to Lyon in 1548, Henry II directed his councillors to reject the city's petition for tax exemption. ${ }^{85} \mathrm{On}$ those occasions when urban grants were terminated, the blame could be attributed to royal officials. In other words, the appearance of unlimited and benevolent royal power was undiminished by the rejection of requests.

As the secrétaires des finances were indispensable to the operation of the royal government, they were admitted to the sittings of both the conseil des affaires and the conseil privé. When the role of the conseil des affaires declined during the mid-sixteenth century, the secretaries filled the vacuum and increased their authority. The chancellor lost some of his powers to the secretaries in the mid-sixteenth century and the secretaries' signature came to

83 Moreau, 'Mémoires d'estat par Monsieur de Villeroy, conseiller d'état et secrétaire des commandemens des rois Charles IX, Henri III, Henri IV, et de Louys XIII', in J.-F. Michaud and J.-J. F. Poujoulat, Nouvelle collection des mémoires pour servir à l'histoire de France depuis le XIII e siècle jusqu'à la fin duXVIII ${ }^{e}$, 1st series, 11 vols (Paris, 1838), xi. 108.

84 Chronique Scandeleuse, i, 36; Johnes, Monstrelet, x. 373.

85 Ам Lyon в в 67 , fol. 281v. 
supersede the chancellor's seal in the issuing of grants. ${ }^{86}$ In 1547 , Henry II raised the principal secrétaires des finances to the position of secretaires d'État. By the mid-sixteenth century the secretaries effectively embodied the executive power of the French state. In 1563, the English ambassador to France, Sir Nicholas Throckmorton, considered Claude de L'Aubespine, secrétaire des finances, to be one of the most influential people in the kingdom. He informed Elizabeth I that L'Aubespine 'principally governs the Queen Mother [Catherine de Medici]', who was then regent of the kingdom. ${ }^{87}$

We can track the political ascendancy of the royal secretaries by examining municipal accounts detailing expenditure on royal entries. The mid-fifteenth century expansion in gift giving reflected France's move towards an increasingly bureaucratic style of monarchy. Urban financial documents detail the array of payments that municipal administrations made to the members of the king's household. While the six offices of the French king's household were in place by the early fourteenth century, the court was not a static entity and the influence of the different offices rose or declined over time. ${ }^{88}$ The shifting internal power networks of the royal household are made clear in urban accounts, as municipal councils gave the most expensive gifts to the people who had most influence with the monarch. Payments to royal secretaries are rare before 1450; indeed, payments to any administrative official beyond the very top rung of royal officers (such as the chancellor) were uncommon. During the fourteenth century, municipal governments tended to restrict their payments to those officials who controlled access to the royal chambers. ${ }^{89}$ When Charles VI entered Mâcon in 1389, the échevins offered gifts to his valets de chambre,

86 Michon, 'Conseils et conseillers', 51-52; Doucet, Institutions de la France, i. 104-9.

87 Joseph Stevenson, Calendar of State Papers, Foreign Series, of the Reign of Elizabeth, 1563 (London, 1869), 542; Sutherland, French Secretaries of State, 112.

88 Élisabeth Lalou, 'Le fonctionnement de l'hôtel du roi du milieu du XIII e au milieu du $\mathrm{XIV}$ e siècle', in Jean Chapelot, ed., Vincennes aux origines de l'état moderne: acts du colloque scientifique sur "Les Capétiens et Vincennes au Moyen Age" (Paris, 1996), 145; Bernard Guenée, States and Rulers in Later Medieval Europe, trans. Juliet Vale (Oxford, 1985), 78. See also: Élisabeth Lalou, 'Hôtel du roi', Lexikon des Mittelalters 5 (1991), 140-41; idem, 'Les ordonnances de l'hôtel des derniers Capetiens directs', in H. Kruse and W. Paravincini, eds., Höfe und Horfordnungen, 1200-1600. 5. Symposium der Residenzen-Kommission der Akademie der Wissenschaften in Göttingen, Sigmaringen, 5-8 Oktober 1996 (Stuttgart, 1999), 91-101; Jules Viard, 'L'hôtel de Philippe VI de Valois', Bibliothèque de l'École de Chartes 55 (1894), 474-87.

89 Aware of their power, the king's ushers offered to admit municipal delegations into the royal residences in return for a cash payment: Lewis, 'Centre and Periphery', 40-41. 
who controlled access the king's rooms. ${ }^{90}$ Before the early fifteenth century, gaining access to the king was often sufficient to have petitions accorded; however, by the end of the century, towns had to make payments to a range of household staff and administrative officials in order to obtain these grants. When Anne of Brittany entered Tours, the municipal council gave gifts of hippocras to the 'financial officers and other great lords and officers of the king' for the efforts they had taken on behalf of the town. ${ }^{91}$ Likewise, the rulers of the Italian cities which came under French rule after 1494 also knew the importance of offering gifts to the French king's principal officials. When Louis XII entered Genoa in 1502, the city council gave gifts to a number of key household officials, with the largest (300 ducats) going to Florimond Robertet, the king's principal secretary. The extent of Genoa's gift giving to the officers of the king's household was so substantial that André de La Vigne (who accompanied Louis on this progress) noted 'there were few officers in the king's household who were not enriched by the gifts of the Genovese. ${ }^{92}$ While the city had just come under French rule, the rulers of Genoa understood that they needed to make such gifts if they wanted their petitions to be successful. ${ }^{93}$

The wages and social status of the royal secretaries increased steadily during the last decades of the fifteenth century. An examination of urban records reflects this rise and reveals a clear expansion in the payments made to royal secretaries from the 1480 s. At Charles vin's entry into Pont-Audemer in November 1487, for the first time the gifts accorded to the secrétaires des finances were second only to those given to the chancellor. ${ }^{94}$ In 1485 , Charles viII granted the privilege of ennoblement to the secrétaires des finances and their descendants were made eligible for entry into any chivalric order after four generations. ${ }^{95}$ The secretaries' consolidation of political power during the later fifteenth century is perhaps best represented by the career of Florimond Robertet. Rising to prominence under Charles viII as secrétaire des finances, Robertet used this position to become a 'veritable minister of finances', before going on to take effective control of the government during the reigns

\footnotetext{
90 Bazin, 'Rois de France à Mâcon', 60.

$91 \quad$ AM Tours AA 4.

92 Godefroy, Cérémonial françois, i. 710-11.

93 For Louis XII's rule at Genoa, see: Steven A. Epstein, Genoa \& the Genoese $95^{8-1528}$ (Chapel Hill and London, 1996), 312-13.

94 See the financial accounts given in: Canel, Histoire de Pont-Audemer, ii. 30-31.

95 Lapeyre and Scheurer, Notaires et sécrétaires du roi, i. xx.
} 
of Louis XII and Francis I. ${ }^{96}$ As the career of Florimond Robertet illustrates, royal secretaries provided a thread of continuity across the reigns of successive monarchs. ${ }^{97}$ While kings and their favourites came and went, the secretaries remained in office. Furthermore, evidence from municipal accounts shows a steady increase in secretarial power under the later Valois monarchs. Significantly, by the mid-sixteenth century the gifts towns offered royal secretaries were no longer classified under the rubric of payments made to the king's domestic staff. ${ }^{98}$ Rather, the secretaries' social status had increased to the point where they were given the most expensive wine (the vin d'honneur), which was customarily reserved for the most important members of the royal entourage. For example, the four principal royal secretaries were amongst the select few who were given high-status wine at Charles IX's entry into Mâcon in $1564 .{ }^{99}$

The longevity of their office and the importance of their position encouraged urban governments to try and construct relationships with the secretaries at royal entries. ${ }^{100}$ In some cases, there were family links between royal secretaries and civic governments, particularly during the late fifteenth century, when urban elites began to use service in municipal administrations as a stepping-stone to advancement in the royal administration. ${ }^{101}$ As David Rivaud has shown, mayors of some towns were drafted into the royal administration during the late fifteenth century. ${ }^{102}$ Indeed, Nicolle Chartier, who was both a royal secretary and the mayor of Tours, was instrumental in planning Anne of Brittany's entry into the town in 1491, as was the Rouennais échevin and royal secretary, Pierre du Couldray, for Henry II's entry into Rouen in $1550 .{ }^{103}$

96 Lapeyre and Scheurer, Notaires et sécrétaires du roi, i. xxiii. See also: Sutherland, French Secretaries of State, 11. For the career of Florimond Robertet, see: Léon Marlet, 'Florimond Robertet, son rôle à la cour et ses missions diplomatiques', Revue des questions historiques 47 (189o), 472-536; G. Robertet, Les Robertet au XVI e siècle, 2 vols (Paris, 1888); Michon, 'Conseils et conseillers', $53^{-} 54$.

97 The secretaries Guillaume Bochetel and Claude de L'Aubespine were amongst the few to survive the transition of power from Francis I to Henry II in 1547: Michon, 'Conseils et conseillers', 54 .

98 See, for example, the financial accounts detailing Abbeville's expenditure on Eleanor of Austria's entry in 1531: Ledieu, 'Élénore d'Autriche à Abbeville', 64-66. AM Mâcon в B 39, fols. 93r-94r.

100 Chevalier, 'King's Council', 112; idem, 'Pouvoir urbain et pouvoir royal à Tours pendant la guerre de Cent Ans', Annales de Bretagne et des pays de l'Ouest 81 (1974), 698-99.

101 Chevalier, Bonnes villes, 135.

102 Rivaud, Villes et le roi, 81-82.

103 AM Tours AA 4; Wintroub, A Savage Mirror, 86. 
As many royal secretaries were drawn from the bourgeoisie, they were in a good position to promote urban concerns with the Crown. After he became a secretary to Louis XI, Thomas Berbisey advanced the affairs of his family, which dominated Dijon's municipal council. ${ }^{104}$ Likewise, the great families from Tours who monopolised the senior financial positions in the royal government at the end of the fifteenth century used their power to advance the commercial activities of their brothers and cousins. ${ }^{105}$ Yet the actions of men such as Berbisey were driven by family interest rather than by a wider championing of urban power. One of the major social shifts of the fifteenth century (which Fernand Braudel memorably termed the 'treason of the bourgeois') was the trend by elite bourgeois families to leave their commercial activities behind in favour of landholding, which brought honour, social mobility and tax exemption. ${ }^{106}$ In return for their service to the Crown, the sécrétaries des finances received lands and property close to the centres of royal power, especially around the Île-de-France and Loire valley. ${ }^{107}$ As these secretarial families moved away from commercial pursuits and married into other landholding families, they had no personal interest in promoting urban concerns.

The establishment of administrative dynasties accelerated the social gulf that was opening up between the secretaries and the bourgeoisie. The ordinance issued by Louis XI in 1482 granting royal secretaries the right to resign their office in favour of a son or son-in-law allowed families such as the Robertet to dominate the higher offices of the royal administration for generations. ${ }^{108}$ In addition, the secretaries consolidated their position through intermarriage. For example, Robert Gedoyn succeeded his father-in-law, Jean Robineau, as royal secretary in 1526, before passing on his position to François Robertet (who was a son of Florimond Robertet). Indeed, the Robertet household provided several prominent royal secretaries, including Gilles Bayard, Jean Breton and most notably Guillaume Bochetel. ${ }^{109}$ As the secretaries constructed dynasties that were based around royal service, the fortunes of their families were dependent

104 Dauphant, Royaume, 357.

105 Chevalier, Bonnes villes, 140; Harsgor, Oligarchies, 187-96.

106 Fernand Braudel, La méditerranée et le monde méditerranéan à l'époque de Philippe II, 2nd edition, 2 vols (Paris, 1966), ii. 68.

107 Lapeyre and Scheurer, Notaires et sécretaires, i. ix. For an image of the scale of the residences given to royal secretaries, see the painting of the château of Le Plessis Bourré, which belonged to Louis xI's secretary Jean Bourré: Ladurie, French Royal State, 18.

108 Lapeyre and Scheurer, Notaires et sécretaires, i. xviii.

109 Michon, 'Conseils et conseillers', 54, 77. For Bochetel's career, see Thierry Rentet, 'Gullaume Bochetel (?-1558)', in Michon, Conseillers de François I ${ }^{e r}, 583-87$; Bruno Garnier, 'Guillaume Bochetel (?-1558): l'irrésistible ascension d'un lettré de province 
on the maintenance of the king's authority. In return for royal advancement, the secretaries worked to promote the power of the monarchy.

In 1531, Francis I appointed his secrétaire des finances, Guillaume Bochetel, to prepare an account of the inaugural entry of his second wife, Eleanor of Austria, into Paris. ${ }^{110}$ In this work, which was published soon after the event, Bochetel presents his readers with a ceremony that was unquestionably a manifestation of monarchical power rather than a moment of dialogue between city and Crown. For the most part, his record of the ceremony emphasises the rigid social stratification observed during the procession and postentry banquet. This was a world in which every person knew his or her place in the hierarchy that underpinned the Crown's conception of the French state. Although Bochetel refers to the gift presentation, he does not mention the requests that Paris's échevins brought to the queen. The interaction between the queen and the city, particularly with regard to the welcoming speech and gift presentation, is entirely absent from Bochetel's work. However, the city's municipal deliberations tell us that Eleanor spoke to the échevins, promising to hold Paris 'always in good and recommended memory' and 'to make pleasure to this town'.111 In contrast, Bochetel finishes his account of the gift-giving ceremony by presenting it as an offering 'to the praise of the queen, and [the] devotion of the Parisians towards her'.112 There is no sense of the reciprocal obligations the gift giving placed on the queen; rather, for Bochetel's readers, the échevins' gift symbolised the city's devotion to the Crown. Bochetel's deliberate attempt to emphasise the submissive role of the city is especially striking when we remember that as a royal secretary he would have been intimately acquainted with the reciprocal nature of gift giving at entries. Bochetel's portrayal of Eleanor of Austria's entry is an example of the slippage between the urban elite's conception of an entry as a moment of dialogue between town and Crown and how the event was presented to a wider audience in the commemorative works published after the entry.

sous François I ${ }^{\mathrm{er}}$, in Stéphan Geonget, ed., Bourges à la Renaissance: Hommes de lettres et hommes de lois (Paris, 2011), 343-65.

110 For the literary works produced by the secretaries of the king, see: Sylvie Charton-Le Clech, Chancellerie et culture au XVI e siècle (les notaires et secrétaires du roi de 1515 à 1547 ) (Toulouse, 1993), 269-85.

111 Guérin, Registres Paris, 1539-1552, 105, 117.

112 Lentree de la Royne en sa ville \& Cite de Paris, Imprimee par le Commandement du Roy nostre Sire (Paris, 1531), p. 21. For the career of Guillaume Bochetel see: Vittorivo Comparato, 'Guillaume Bochetel, secrétaire d'Etat (?-1558)', in Mousnier, Conseil du roi, 105-29. 
By the mid-sixteenth century, the secrétaires des finances were at the centre of government. Their dominant role in the conseil privé was of particular importance for civic administrations because this council travelled with the king and oversaw the issuing of petitions. Shortly after Henry II's coronation, Paris's échevins stated that it was necessary to bring the city's business to the attention of the king and the conseil privé. ${ }^{113}$ As it was difficult for urban administrations to gain admittance to meetings of the conseil privé, those household officials who regulated access to its sittings could offer their services to civic leaders. In advance of Henry II's entry in Amiens in 1558, the capitaine de la porte du roi, who controlled access to the king's lodging while on progress, solicited the municipal council for a golden key at the king's entry. In return for this gift, the captain offered to admit the échevins to a sitting of the conseil privé, where they could speak to its members about the city's business. ${ }^{114}$ This was an attractive offer for the échevins, who decided to offer the gift to the captain. Access to the sitting of the conseil privé allowed municipal councils to explain the necessity of their requests directly to the royal secretaries and other council members.

The king rarely attended the daily sittings of the conseil privé, which is highlighted by the fact its arrêts were largely made 'by the king in his council', in contrast to 'the king being in his council', which was used when the monarch was present. While the chancellor presided over the conseil privé in the absence of the king, the secretaries made the decisions regarding petitions. ${ }^{115}$ It is significant that while Lyon's council declined to give the chancellor a gift at Henry II's entry in 1548 , they offered high-quality wine to Jean de La Chesnaye, who was a royal secretary and the controleur général des finances. The town council even approached La Chesnaye's sommelier to learn what his favourite type of wine was. In return for this gift, the consuls wanted La Chesnaye to persuade the conseil privé to grant the petition for tax exemption they planned to submit at Henry's entry. ${ }^{116}$ Once the secretaries had decided what petitions to approve, the grants were written down a roll and brought to the king to sign. Following his entry into Agen on 23 March 1565, Charles IX verbally confirmed the town's request for annual elections of the consuls. These requests were then

113 Godefroy, Cérémonial françois, i. 298.

114 Ам Amiens B В 31, fol. 124v; A. Dubois, Entrées royales et princières dans Amiens pendant les $15^{e} \& 16^{e}$ siècles (Amiens, 1868), 44.

115 Michon, 'Conseils et conseillers', 36.

116 Ам Lyon вв 67 , fol. 243 v. 
brought the royal secretaries, who approved and registered them before the king left the town on 27 March. ${ }^{117}$

Civic administrations were required to pay royal secretaries to ensure that this process was completed. When Louis XII entered Pontoise on 28 October 1508 , he granted the town council the right to collect the profits on the sale of salt for eight years. In order to have the king's grant ratified, the échevins were obliged to make a number of payments. First, they paid 18 écus to Florimond Robertet, the général des finances. Second, they made a payment of 25 livres 10 sous to have the correct seals put on the documents. The use of green wax was crucial as it showed the clerks of Cour des Aides (where the final grant was registered) that the secretaries had ratified the king's concession. ${ }^{118}$ Third, the échevins paid 4 livres 12 sous 'for the verification of the said letters'. Finally, once Robertet had approved their petition, Pointoise's leaders had to pay a further 3 livres 12 sous to his clerks to have them registered. ${ }^{119}$ The king's grant of the salt tax was only official once all the stages in this process were complete.

These payments (which were made in addition to the gifts of wine) formed part of the profits which royal secretaries could legally make on all the grants they issued. From 1389 , the secretaries had the right to claim 5 sous on all charters they sealed with green wax (as well as the right to food and lodgings for themselves and their servants). ${ }^{120}$ However, this system was open to abuse and officials could demand additional payments from town councils to confirm royal grants. When Louis XI entered Lyon in 1474, he approved the city's petition to compel townspeople who possessed properties and estates in the surrounding countryside to contribute towards the taille for these lands. This was part of a long-running dispute with local villages regarding the payment of the taille on the rural properties owned by the city's bourgeois. This issue was becoming more common in France from the late fifteenth century because increasing numbers of wealthy townspeople were moving into landholding. As David Potter had observed, exemption from this tax generated great bitterness because it placed an additional financial burden on the native rural population, which was already heavy as a result of the widespread exemptions from

117 Auguste, Inventaire sommaire, Agen, 29.

118 For the sealing of such documents, see: Barbiche, 'Gardes des sceaux', 359-90; Roland Mousnier, The Institutions of France under the Absolute Monarchy 1598-1789. Vol. II: The Organs of State and Society (London, 1984), 136-38.

119 J. Depoin, 'Entrée de Louis XII et d'Anne de Bretagne à Pointoise, 1508', Bulletin de la Société de l'histoire de Paris et de l'Ile-de-France 2 (1875), 167-68.

120 Davis, The Gift, 144; idem, Fiction in the Archives, 10, 153; Michaud, Grande chancellerie, 113,295 . 
the taille urban governments obtained at royal entries. ${ }^{121}$ Yet, as this example reveals, townspeople's exemption from taille payments on their rural properties was also a matter of some concern for urban governments. It was of particular interest to Lyon's consuls because the townspeople who purchased land in the countryside had it taxed at their principal urban residence. Although this move was to the detriment of the rural population, it benefitted municipal governments because as Daniel Hickey has observed it widened the tax base of the town without increasing its assessment and therefore lowered the taille rate for each unit of town property value.'122 While the taille in the south was largely assessed by the status of the land (taille réele - see chapter 2), Lyon's merchants insisted on the taille being assessed on terms of social status from the late fifteenth century. By claiming exemption from the taille for these properties, Lyon's land-holding merchants also increased the tax burden that fell on the rest of the city's population, especially other members of the elite. This was particularly serious when a town or city had not already secured a taille exemption, as Lyon had not in 1474.

As the Crown received numerous appeals about individual taille exemption, it was crucial that city councils capitalised on the access they had to the king and his officials at an entry to have the matter settled in their favour. Certainly, Lyon's consuls worked to ensure that Louis XI's officials ratified his grant so that they could continue to collect the tax from urban landholders. ${ }^{123}$ On 5 May 1476, the consuls paid six écus to the royal secretaries Estienne Petit and Loys Daniel and their clerks 'for having drawn up, corrected and written out the final version' of the king's grants. In addition to these payments, they offered smaller sums of money and gifts of cloth to Aynard Eschat to have Guillaume Le Picard (général des finances de Normandie) check the letters detailing the awards the king had verbally granted them. While this process ensured that the letters they submitted to the royal officers were in order, the grants were only legal once they had obtained the correct seals. Aware of the uncompromising situation that Lyon's rulers were in, the king's audiencier, contrôleur and royal secretaries steadily increased the money they demanded from Lyon's consuls in 1476 to have the necessary seals placed on the documents. Although the consuls considered these sums to be 'excessive and exorbitant', there was little they could do but make these additional payments, otherwise all the

\footnotetext{
121 Potter, Nation State, 152.

122 D. Hickey, The Coming of French Absolutism. The Struggle for Tax Reform in the Province of Dauphiné, 1540-1640 (Toronto, 1986), 20.

123 Watson, 'Friends at Court', 282.
} 
expense and effort they had taken for the entry would be lost. ${ }^{124}$ Urban governments complained about the financial cost of obtaining the confirmation of their liberties; indeed, the widespread corruption amongst the royal officials who ratified municipal liberties was condemned at the Estates General held at Tours in $1484 .{ }^{125}$

As royal visits were often short, it was not always possible for urban administrations to complete all the stages of the grant verification process before the king's departure, even during longer stays in larger cities. Although Henry II gave Rouen the right to levy a number of aides at his entry in 1550, the municipal council had to send a delegation to follow the royal household to Dieppe to obtain the ratification of these grants. As the royal council did not meet in Dieppe they were forced to continue their journey to Vatteville, where the chancellor finally ratified their grants at a meeting of the conseil privé held on 25 December 1550 - almost seven weeks after the king had initially granted their requests. ${ }^{126}$ Small towns faced further complications in obtaining the ratification of royal grants because they often lacked lawyers with the necessary expertise to draw up the petitions that were submitted to royal secretaries for inspection. In such cases, the municipal council's key concern was to ensure that they obtained the king's verbal approval of a grant at the entry, which they could pursue with his secretaries later. The rulers of the small Limousin towns of Brive-la-Gaillarde and Uzerche obtained grants from Louis XI during his 1463 progress. As the king's visits to Brive and Uzerche were brief, the consuls of both towns sent representatives to follow the court to the provincial capital of Limoges, where they hired lawyers to draft the letters for the royal secretaries. As these documents took some time to prepare, the municipal delegations had to follow the royal cortege to Amboise, where they were able to have their grants confirmed and sealed in green wax. ${ }^{127}$

In order to accelerate the process - and to make sure that they received the grants before the king left their town and passed out of their control - some town councils brought details of their petitions to royal officials in advance of a royal entry. Before Henry II entered Rouen in 1550, the town council approached the members of the royal council and informed them about the tenor of the petitions they planned to bring to the king at his entry. ${ }^{128}$ There

\footnotetext{
124 Guenée and Lehoux, Entrées royales françaises, 223.

125 Jean Masselin, Journal des état-généraux tenus à Tours en 1484, sous le règne de Charles VIII, ed. A. Bernier (Paris, 1835), 684-85.

126 Beaurepaire, Inventaire sommaire, Rouen, 172.

127 Jean-Paul Lartigue, Louis XI en Bas-Limousin 1463 (Brive, 1963), 16.

128 AD Seine-Maritime, Am Rouen A 16, fol. 116r.
} 
were two principal benefits to entering into pre-entry negotiations with royal officials. First, it was a sensible and effective means of reducing uncertainly in the process of petitioning. Second, it sped up the ratification of the grants by cutting down the time it took royal secretaries to inspect the grants. When Troyes' municipal council learned that Louis XII planned to make an entry into the town in 1510, the échevins decided to seek the abolition of a tax. Aware of the potential difficulties with this request, the councillors brought the details to the chancellor and the géneraux des finances (who were often royal secretaries) for inspection before they approached the king. Louis's officers found that the abolition of the tax was unreasonable, given that it generated between 800 livres and 1000 livres annually for the Crown. As a result of this ruling, Troyes' rulers entered into negotiations with royal officials to devise petitions that would be mutually acceptable for town and Crown. Louis's officers told the échevins that if they continued to farm the tax on behalf of the Crown, the king would grant Troyes a free fair of fifteen days. This grant gave the municipal council the chance to put Troyes back on the commercial map, as Lyon had supplanted the fairs of Champagne in the fifteenth century. The échevins brought their requests to Louis, who approved them, and with no further delay the grants were drawn up, sealed and registered at the Cour des Aides. ${ }^{129}$ These strategies allowed towns to successfully negotiate with the Crown regarding grants while they still had access and direct contact with the king and his principal ministers. Once the court had moved on to another town, the costs and difficulties of having grants registered - even when they already had been made - increased substantially. In order to gain as much contact as possible with the king and his leading officials (and thus speed up the grant-awarding process), municipal councils sought the assistance of the servants and lesser officials who travelled with the royal party.

\section{Domestiques et Commensaux du Roi}

Although the king's household included the most senior officials in the kingdom, an array of lower officers and domestic servants formed the bulk of the Domestiques et Commensaux du Roi. ${ }^{130}$ These men and women cared for the physical and spiritual needs of the king, and included physicians, apothecaries and musicians, as well as porters, washerwomen and quartermasters.

\footnotetext{
129 Babeau, Rois de France à Troyes, 24-25.

130 Forty-three distinct categories of household staff are listed in the estat of the king's household compiled in 1536: Zeller, Institutions, 101.
} 
Despite forming the greater part of the royal household, historians have overlooked the vital role that these officials and servants played in linking the courtly and urban worlds during a provincial progress. They were particularly important for urban administrations because the nature of their tasks (which included securing the king's lodgings and provisions) brought them into contact with a wide range of urban groups.

While payments to the king's domestic staff are apparent from the late fourteenth century, the extent of these sums remained modest until the mid-fifteenth century, largely due to the small size of the Valois court. ${ }^{131}$ For example, the only payments Mâcon made to Charles vi's household staff at his entry in 1389 were fifty sous to his valets de chambre (see above) and ten sous to his minstrels. ${ }^{132}$ Yet the range of these payments increased steadily as a consequence of the steady growth in the size of French king's household from the mid-fifteenth century. While ninety officers served Louis XI in 1465, three hundred and sixty-six people tended to his son, Charles viII. The size of the king's household exceeded one thousand people during the reign of Henry II and it continued to grow under his successors. ${ }^{133}$ As household expenditure swelled when the size of the court grew, the French king increasingly insisted that civic councils were obliged to cover these costs during a royal visit. The Valois monarchy reduced its household expenditure by embarking on a progress, as this allowed it to place the costs of feeding the household on the towns and cities of the kingdom. ${ }^{134}$ Once the court drained a town of its resources, it moved on to another. The English ambassador who accompanied Charles IX on progress remarked that the monarch left Toulouse on 19 March 1565 after a stay of forty-six days because food was running short in the city. ${ }^{135}$ The Valois court then travelled to Bordeaux where the costs of feeding the royal household almost led to the city's financial collapse. ${ }^{136}$ By travelling from town to

\footnotetext{
131 Jeroen Duindam, Vienna and Versailles: The Courts of Europe's Major Dynastic Rivals, 1550-1780 (Cambridge, 2003), 30-31.

132 Bazin, 'Rois de France à Macon', 60.

133 Monique Chatenet, La cour de France au XVIe siècle: vie sociale et architecture (Paris, 2002), 26-27; Yvonne Labande-Mailfert, Charles VIII et son milieu, 1470-1498: la jeunesse au pouvoir (Paris, 1975), 139-44. In 1584, the size of Henry III's household stood at 1094: Jacqueline Boucher, La cour de Henri III (Rennes, 1986), 359-79.

134 Solnon, Cour de France, 19.

135 Hector de la Ferrière, ed., Le XVI e siècle et les Valois d'après les documents inédits du British Museum et du Record Office (Paris, 1879), 183. Out of the 30,00o livres Toulouse spent on Charles IX's entry, 12,00o livres went towards the costs of feeding the king's entourage: Vaillancourt, Entrées solennelles, Charles IX, 15 .

136 Solnon, Cour de France, 57.
} 
town, the monarch was able to sustain the appearance of largesse and liberality without incurring the financial cost.

In particular, municipal authorities were required to provide subsistence to the Domestiques et Commensaux du Roi - the permanent members of the king's household who possessed table rights. The increased emphasis on civic responsibility to pay for the upkeep of royal staff is reflected in the language of urban financial accounts. Under Louis XI, payments were made to members of the king's household staff 'for the honour and love of the king' ${ }^{137}$ By the reign of Charles VIII, however, royal officers increasingly asserted that these were customary payments rather than voluntary grants made in honour of the king's presence. When Charles viII entered Pont-Audemer in 1487, his héraults d'armes claimed 4 livres 5 sous from the échevins as their right at a royal entry ('pour leur droit de l'entrée du roi'). ${ }^{138}$ This was a key phrase and it was used throughout the sixteenth century. When Henry II entered Mâcon in 1548, the échevins paid his household staff a sum of money 'for a certain right which they say they have at each entry' ${ }^{\prime 39}$ The household's staff insistence on their right to these payments became especially pronounced during the reign of Francis I, who attempted to slash royal expenditure by limiting access to table rights. ${ }^{140}$ When Mantes' town council failed to pay the customary sums to the members of Eleanor of Austria's household in 1536, the disgruntled officials demanded six écus from the échevins, claiming they were entitled to this sum each time the king or queen ceremonially entered a town. ${ }^{141}$

Municipal councils attending an entry in a neighbouring town could also choose to make these payments to household staff. On 29 March 1492, PontAudemer's échevins sent a delegation to Honfleur to attend the entry of Louis, duke of Orléans, and offer their petitions. Pont-Audemer's financial accounts note that the échevins gave four écus 'to the quartermasters, trumpeters, heralds and chamber guards of the lord, being at the entry, as they say they are accustomed to take from the good towns where the lord makes his entry.'142 Despite the claims of Louis's staff, the municipal council was not obliged to

\footnotetext{
137 Guenée and Lehoux, Entrées royales françaises, 198.

138 Michelin, 'Pont-Audemer', i. 26o. See also: Canel, Histoire de Pont-Audemer, i. 31. Likewise, Charles's staff made similar claims at his entry into Évreux in 1485: Benet, 'Charles VIII à Evreux', 170.

139 Bazin, 'Rois de France à Macon', 81.

140 Duindam, Vienna and Versailles, 31; Potter, Nation State, 70.

141 Alphonse and Eugène Grave, La Chronique de Mantes; ou histoire de Mantes depuis IX $X^{e}$ siècle jusqu'à la Révolution (Mantes, 1883), 313.

142 Given in Canel, Histoire de Pont-Audemer, i. 43. They had to make further payments when Louis of Orléans entered Pont-Audemer later that year: Michelin, 'Pont-Audemer', iii. 104.
} 
cover the expenses of the duke's officials as he was not entering Pont-Audemer; this was the responsibility of Honfleur's échevins. Nonetheless, it was in PontAudemer's interests to make these payments because Louis was emerging as one of the most powerful figures in the kingdom in 1492. Not only had Charles viII pardoned Louis for rebelling against the Crown in the 1480s, he had also made him governor of Normandy. ${ }^{143}$ As such, it was desirable for municipal councils situated in his gouvernment, such as Pont-Audemer, to gain contact with the duke. Given the central role that members of the household staff played in providing access to those in power, they were able to demand these payments from municipal councils. Indeed, the value of the payments made by Pont-Audemer became clear when the duke of Orléans ascended to the throne as Louis XII in 1498.

There was a difference between the status of the gifts offered to senior officials in the royal administration and the payments accorded to domestic staff. In contrast to the gifts of wine and silverware handed over to people such as the chancellor and the sécretaires des finances, cash payments to servants and lower household officials were not given with the expectation of reciprocity. In pre-modern French the noun 'gift' (don) and the verb 'to give' (donner) were used when the gift giving implied an exchange. As Alain Guéry notes, 'a reciprocal relationship is contained in the original meaning of the word gift'. 144 Tournai's financial accounts for Louis XI's entry in 1463 illustrate the distinction between the two types of gifts. Tournai's treasurer used the word 'don' when detailing the luxury gifts of food, wine and silverware that the échevins gave to those people in Louis's entourage who had influence with the monarch, including the chancellor, Pierre de Morvilliers, and the king's brother, Charles, duke of Berry. In return for the provision of these gifts, Tournai's municipal council expected the chancellor and duke to perform services for the city. In contrast, the payments to the staff of the royal household ('gens et privez serviteurs de l'Ostel du roy') were 'distributed by form of courtesy'.145 In other words, the receipt of these gifts did not oblige the beneficiary to reciprocate.

Nonetheless, the provision of payments to domestic staff promised to benefit municipal councils. The people who filled the lower positions of the

\footnotetext{
143 Knecht, Renaissance France, 29.

144 Alain Guéry, 'Le roi dépensier. Le don, la contrainte, et l'origine du système financier de la monarchie française d'Ancien Régime', Annales E.S.C. 39 (1984), 1243. See also: Émile Benveniste, 'Don et échange dans le vocabulaire indo-européen', in Émile Benveniste, Problèmes de linguistique générale, 2 vols (Paris, 1979-80), ii. 315-26; Mauss, The Gift, $37-41$.

145 Guenée and Lehoux, Entrées royales françaises, 198.
} 
royal household pursued a range of occupations that were indispensable to the running of the court and they were permitted to reside at court permanently. Although the social status of the recipient partly determined the size of the payments, municipal councils targeted those members of the household staff who could provide access to the king. In the fifteenth century, municipal councils gave the most substantial sums of money to the king's personal guard (hussiers). When Charles VII entered Rouen in 1449, the town council made payments to all the members of the king's household but 'especially to the huissiers d'armes'.146 As the hussiers guarded the king and controlled the access to his chambers, they were able to admit municipal councils into his presence to offer him their petitions. In addition to the hussiers, municipal councils targeted royal confessors with substantial gifts in the fifteenth century. This was an intelligent choice because confessors had regular and intimate access to the royal family, while their power over the king's spiritual wellbeing placed them in a privileged position to influence royal policy.147 Confessors often had links with municipal administrations, which made them good go-betweens. ${ }^{148}$

During the second half of the fifteenth century, the power of the huissiers waned as other groups superseded them. In particular, municipal councils began allocate the highest payments to the fourrière (the office of the quartermaster), which prepared the king's lodgings in advance of his arrival in the town. ${ }^{149}$ The quartermasters (fourriers) were key officials for urban

146 Beaucourt, Chronique de Mathieu d'Escouchy, i. 243; Courteault and Celier, Chronique de Charles VII, ii. 328.

147 For payments to confessors, see: Leroux, 'Passages de Charles VII', 307-8; Tricard, 'Entrées royales à Limoges', 407; Douët-d'Arcq, Chronique de Monstrelet, iv. 24; Ам Orange в в 8, fol. 104r. For the influence confessors held with early modern monarchs, see: Magdalena S. Sánchez, The Empress, the Queen, and the Nun: Women and Power at the Court of Philip III of Spain (Balitmore and London, 1998), 16-21; Benoist Pierre, 'Le clergé de cour et la décision politique dans la première moitié du XVI ${ }^{\mathrm{e}}$ siècle', in Claerr and Poncet, Prise de décision, 54-62; Joseph Bergin, 'L'essor du confessor du roi au XVII ${ }^{\mathrm{e}}$ siècle', in Denis Lopez, Charles Mazouer and Éric Suire, eds., La religion des élites (Tübingen, 2008), 111-26; Joseph Bergin, 'The royal confessor and his rivals in seventeenth-century France', French History 21 (2007), 187-204.

148 For example, Francis I sent his confessor to Rouen's town council with royal letters in May 1512: AD Seine-Maritime, AM Rouen A 10, fol. 105r.

149 Though the hussiers and portiers remained important officials for towns to target as they continued to control access to the royal chambers. When Francis II and Mary Stuart entered Tours in 1560, the municipal council paid 13 écus (32 livres 10 sous) to their hussiers and portiers: AM Tours CC 77. 
governments as they organised the court's lodgings. ${ }^{150}$ The importance that municipal councils attached to the fourriers is illustrated by the fact that while the écurie (stable) was the most senior office in the French king's household by the sixteenth century, the largest payments were given to the fourriers. When Francis I entered Évreux on 9 September 1517, his fourriers received fifteen écus (450 livres), which was the largest single sum paid to the king's household staff. ${ }^{151}$ At the previous royal entry into the town (Charles VIII in 1485), the fourriers only received 3 écus (go livres). ${ }^{152}$ The fourrière maintained its dominant position throughout the sixteenth century. When Henry II entered Amiens in 1558, the king's fourriers continued to receive the greatest sums of money (10 écus) from the échevins. ${ }^{153}$ The same was true for the entries of the queen of France. At Eleanor of Austria's entry into Abbeville, the fourriers received the highest payments of the queen's domestic servants, while Tours' municipal council gave the fourriers of Francis II and Mary Stuart 20 écus (50 livres) in 1560 because they were accustomed to receive this amount at the king's entries. ${ }^{154}$

The fourriers were given these high payments because they provided a vital link between Crown and town. As the fourriers preceded the king's arrival in a town by several days in order to organise the lodgings for the royal party, they had extensive contact with civic officials in the run up to an entry. Municipal councils used this time to develop friendly links with the fourriers by providing them with high-quality food and drink that went beyond the customary payments they received at an entry. For instance, in the days leading up to Louis XII's entry into Dijon in 1501, the municipal council spent the considerable sum of 55 livres entertaining the king's fourriers. To put this into perspective, the civic administration's expenditure on the fourriers in advance of the entry was only three livres less than the total cost of the gifts and provisions they offered to all the other members of Louis XII's domestic staff during his visit to the town. ${ }^{155}$ Similarly, Abbeville's municipal council paid the sum of 36 livres 15 sous 3 deniers to the innkeeper Nicholas de Broustelles and the cook Jehan Mourrier 'for the expenses made by the maréchal des logis and fourriers of the king and queen' during the four days they spent in the town organising

150 Vaillancourt, Entrées solennelles, Charles $I X, 56$. For an outline of the fourriers' duties for a royal entry, see: Varin, Archives administratives, Reims, ii. 564.

151 AM Évreux CC 52, no. 82.

$15^{2}$ Benet, 'Charles VIII à Evreux', 171.

153 Aм Amiens Bв 24, fol. 288r.

154 Ledieu, 'Élénore d'Autriche à Abbeville', 65; AM Tours CC 77.

155 Gouvenain, Inventaire sommaire, Dijon, ii. 6. See also: Ledieu, 'Élénore d'Autriche à Abbeville', 72; Ам Mâcon вв 22, fol. 89 r. 
residences for the royal entourage. ${ }^{156}$ Indeed, urban administrations treated the fourriers more akin to the elite officials who travelled with the king (such as the chancellor), rather than domestic staff.

In return for treating the fourriers favourably, municipal councils hoped to influence the lodgings they chose for the principal members of the royal entourage. In preparation for Louis XII's entry into Troyes on 21 July 1500, an urban delegation accompanied the king's fourriers as they marked out the residences designated to receive the monarch and the most important members of his entourage. ${ }^{157}$ Likewise, when Charles viII entered Pont-Audemer in 1487 , the financial deliberations note that the king's fourriers were given 10 livres 'in order to have the lodgings of the bourgeois and inhabitants in good recommendation. ${ }^{158}$ Municipal councils wanted the important members of the king's entourage to stay in bourgeois households during a royal visit as it afforded them access to people who had the king's ear. For example, when Francis I entered Dijon in $15^{21}$ the governor, Louis de La Trémouille, was lodged at the house of Jean Chisseret, who was paid 20 livres by the échevins. ${ }^{159}$ Nonetheless, the wider urban population did not share the elite's desire to gain access to those in power. As we saw in chapter two, householders resisted efforts to have members of the court lodge with them, which meant that municipal councils frequently had to compel townspeople to welcome these guests. By offering hospitality and gifts to the fourriers, municipal councils hoped to reduce tensions between the townspeople and the king's officers. In advance of Louis XI's entry into Lyon in 1476 , the consuls gifted wine and 10 livres to the king's fourriers 'in order that in their duties they [the fourriers] treat the inhabitants of the town softly'.160 Likewise, when Louis de La Trémouille, the governor of Burgundy, entered Dijon in 1524 the échevins paid 4 livres to both of his fourriers 'in order that they treat the habitants graciously when organising the lodgings of my lord the governor and madame his wife, and also that they have a good report of the habitants.' ${ }^{161}$ In essence, urban governments wanted the fourriers to treat the bourgeois householders with courtesy as ill feeling towards the lodging of nobles damaged the municipal council's efforts to promote civic interests with members of the king's entourage.

\footnotetext{
156 Ledieu, 'Élénore d'Autriche à Abbeville', 72.

157 Babeau, Rois de France à Troyes, 7.

158 Canel, Histoire de Pont-Audemer, ii. 31.

159 Gouvenain, Inventaire sommaire, Dijon, iii. 8.

160 Guenée and Lehoux, Entrées royales françaises, 222.

161 Gouvenain, Inventaire sommaire, Dijon, ii. 16.
} 
Furthermore, fourriers had the power to determine whether or not the king visited the town. As plague was endemic in France, royal fourriers were sent into a town in advance of an entry to check for the presence of the disease. If they found that plague was present, the king would not enter. Charles viII cancelled many of his customary post-coronation entries because of an outbreak of plague. ${ }^{162}$ Urban governments needed to convince the fourriers that there was no epidemic disease present in their towns, particularly in areas where plague was known to be present. In the run up to a royal entry, municipal governments took steps to contain outbreaks of epidemic disease. When Mâcon's échevins discovered the presence of plague in the neighbouring village of Plotes just in advance of Louis XII's entry in June 1501, they sent sergeants to the village to prevent its residents from travelling to the town for the king's entry. ${ }^{163}$ When Louis XII planned to return to Mâcon in 1510, the échevins again uncovered the presence of plague in several neighbouring villages. In response, they forbade anyone from these villages from entering the town under pain of being hanged. ${ }^{164}$ Municipal councils hoped that the introduction of diligent antiplague measures would persuade the fourriers that their towns were healthy. In advance of Louis XII's entry into Valence in 1503, the consuls' implementation of plague ordinances convinced the king's fourriers that the town had been free of plague for three months. ${ }^{165}$ It was crucial for urban governments to ensure that the king made an entry, as they stood to lose the opportunity to present him with their petitions. Some towns were even prepared to lie about the presence of plague (and thus run the risk of infecting the royal entourage) in order to have the king enter. When Charles IX entered Valence in 1564, the municipal administration concealed an outbreak of plague for the duration of the royal visit. ${ }^{166}$

Overall, the lower and mid-ranking officials of royal households gained considerable power during a ceremonial entry because their control over royal residences and itineraries placed them in an ideal position to assist municipal councils in a range of ways. In return for facilitating access to the king and the

\footnotetext{
162 BNF Collection de Picardie 5, fols. 12r, 121r; AD Oise, Aм Senlis Bв 3, fol. 51r; P. Pélicier, ed., Lettres de Charles VIII, roi de France, 4 vols (Paris, 1898-1905), i. 40.

163 AM Mâcon вв 22, fols. 89r-92r; Bazin, 'Rois des France à Mâcon', 66.

164 Rose, Inventaire sommaire, Beauvais, 73-74. For measures against epidemic diseases during royal entries, see also: BM Beauvais Coll. Bucquet, vol. 57, p. 371; Ам Compiègne в В 13, fol. 5 ov.

165 André Lacroix, Inventaire sommaire des archives communales et des archives hospitalières de la ville de Valence antérieures à la Révolution et inventaire sommaire des archives communales de Die et Montélimar (Valence, 1994), 18.

166 Lacroix, Inventaire sommaire, Valence, 43.
} 
most important members of his entourage, groups such as the fourriers and hussiers were able to profit from a royal entry.

\section{Royal Women and Royal Entries}

The final section of this chapter examines the king's female relations, who were amongst the most influential people in the kingdom. As these women's entries reflected the king's authority, Valois monarchs wrote to municipal governments to encourage them to prepare magnificent receptions for their female kin. On 7 November 1504, for example, Louis XII wrote to the Parisian town council asking it to receive his second wife, Anne of Brittany, 'as you would ... our own person' ${ }^{167}$ Although the French kings and queens could progress around the kingdom together, the monarch and his spouse tended to enter towns separately. It was not customary for French kings to attend their wives' entries in a formal capacity, though some monarchs watched these receptions clandestinely. ${ }^{168}$ As such, they could see how the queen was received. With the monarch's gaze on them, urban governments devised lavish entries that credited both the king and the town. For example, Paris's échevins decided to grant a canopy to Claude of France in 1517 'for the honour of the King and of the town'. ${ }^{169}$ By devising magnificent entries for royal women, urban administrations hoped to recommend themselves to the king. When Rouen's rulers learned that Queen Isabella intended to visit the city in May 1390, they devised a magnificent entry 'to keep the honour of the town.' ${ }^{170}$ French town councils prepared splendid receptions for royal women which emphasised the dignity of the Valois monarchy and thus endeared the citizens to the king. ${ }^{171}$

Urban governments stood to profit from staging entries for royal women. According to the Chronique du religieux de Saint-Denis, the Parisians hoped that Isabella of Bavaria's entry into Paris in 1389 would lead to a reduction of the city's tax burden. ${ }^{172}$ The Parisian elite was also able to use the queen's

\footnotetext{
167 Bonnardot, Registres Paris, 1499-1526, 93.

168 Fanny Cosandey, La Reine de France. Symbole et pouvoir, XV ${ }^{e}-X V I I I^{e}$ siècle (Paris, 2000), 186.

169 Bonnardot, Registres Paris, 1499-1526, 248.

170 AD Seine-Maritime, AM Rouen A 1, fol. 8r.

171 See also: Claire Dolan, 'Rites d'accueil, identité urbaine et représentation politique à Aix-en-Provence au XVIe siècle', in Massimo Miglio and Giuseppe Lombardi, ed., Simbolo e realtà della vita urbana nel Tardo Medioevo (Manziana, 1993), 289-90.

172 Bellaguet, Chronique de Saint-Denys, i. 616.
} 
entry to gain an audience with Charles VI. Before going to offer their gifts to the queen, the town council first went to present gifts to the king in his chambre in the royal palace. ${ }^{173}$ The following year, Rouen's échevins used Isabella's entry to petition Charles vi for an octroi on wine sold in the city. ${ }^{174}$ As kings regularly travelled with their female relatives, royal entries provided the rulers of provincial towns with a further opportunity to present their petitions to the king. When Mary Tudor entered Beauvais in 1514, the échevins gave Louis XII requests seeking exemption from taxes on the sale of fish as well measures relating to the fabrication of cloth in the town's suburbs. ${ }^{175}$ The honourable treatment of the queen encouraged French kings to make grants to urban communities. Following Louis XII's entry into Valence in July 1511, the consuls offered to escort his wife to Lyon at the city's cost. In return for this respectful treatment of his wife (which went beyond what the town was obliged to provide), Louis gave the consuls twenty muids of salt. This was a lucrative grant for the town council as salt was expensive (twenty muids of salt cost 900 florins). Furthermore, as this was a gift from the king, it was exempt from the salt tax (gabelle), thus saving the consuls a further hundred florins. ${ }^{176}$ Indeed, the salt tax was such a critical issue in sixteenth century France that it led to a revolt against the Crown at Bordeaux in the summer of 1548.177

Of greater value to municipal governments than these short-term financial concessions were the longer-term benefits that came from recruiting royal women as brokers. The intimate nature of these women's relationships with the king gave them considerable power to assist urban governments. ${ }^{178}$ To take one example, Louis XII granted new liberties to Étaples after a receiving a request from his daughter Claude on her wedding day. ${ }^{179}$ The nature of the

173 J. A. C. Buchon, ed., Chroniques de Froissart, 15 vols (Paris, 1824-28), xii. 24-25.

174 AD Seine-Maritime, AM Rouen A 1, fol. 8r.

175 Bм Beauvais, Coll. Bucquet, vol. 57 , p. 373 .

176 Aм Valence Bв 4, fols. 15r, 23r.

177 Tatiana Baranova, 'Le discours anti-tyrannique dans la France d'Henri II: un des sens multiples du Pasquille sur la rébellion de Bordeaux et la conduite du connétable', Histoire, économie, société 21 (2002), 479-500; Anne-Marie Cocula, “Je vis en mon enfance un gentilhomme commandant a une grande ville”: Montaigne et la révolte Bordelaise de 1548', in Bernard Babiche, Jean-Pierre Poussou and Alain Tallon, eds., Pouvoirs, contestation et comportements dans l'Europe moderne. Mélanges en l'honneur du professeur Yves-Marie Bercé (Paris, 2005), pp. 531-47; S.-C. Gigon, La révolte de la gabelle en Guyenne (Paris, 1906).

178 Diana Pelaz Flores, 'Queenly Time in the Reign of Juan II of Castile (1406-1454)', in Elena Woodacre, ed., Queenship in the Mediterranean: Negotiating the Role of the Queen in the Medieval and Early Modern Eras (Basingstoke, 2013), 169-90.

179 Wilson-Chevalier, 'Claude de France', 130. 
king's relationships with the women in his life put them in a particularly good place to influence his decisions. The blurring between the private and public spheres of the French monarchy meant that royal women held considerable influence with the king, which could be used to promote municipal affairs. ${ }^{180}$ They had a back-room communication with the king and were permitted entry into spaces that were denied to most members of the royal household. Accordingly, royal women had the potential to be key brokers for urban governments, which was especially important from the mid-sixteenth century when access to the king became increasingly restricted.

Municipal councils drew on models of female intercessory power to persuade royal women to act on their behalf. ${ }^{181}$ When Francis I and his wife Claude entered Poitiers on 5 January 1520 the consuls likened the queen to Radegund in their welcoming speech and presented her with a silver statue of the saint. ${ }^{182}$ Radegund was a good model of intercessory queenship for the consuls because the sixth-century Merovingian queen had used her influence with her husband (the Frankish king, Clothar) to persuade him to make grants to found religious houses. ${ }^{183}$ Furthermore, as Radegund lived in Poitiers she embodied local identity and emphasised the special links that existed between the queens of France and the city. Changing fashions in the design of entries during the mid-sixteenth century led urban governments to include references to elite Roman women noted for the influence they held over their sons. When Catherine de Medici entered Sens in 1564, the échevins referenced Julia Mamaea in their greeting speech. This powerful member of the Roman imperial family had held considerable influence with her son, Emperor Severus Alexander, who followed his mother's advice to improve economic conditions in the Roman state, particularly through the reduction of taxes and the stabilisation of the currency - issues that were of as much concern to the townspeople of sixteenth-century France as they were to third-century Romans. ${ }^{184}$ As well as

180 Theresa Earenfight, 'Without the Person of the Prince: Kings, Queens, and the Idea of Monarchy in Late Medieval Europe', Gender and History 19 (2007), 9.

181 Cosandey, Reine de France, 195.

182 Rivaud, Entrées princières, 129.

183 Suzanne Wemple, Women in Frankish Society: Marriage and the Cloister 500 to 900 (Philadelphia, 1981), 61; Jo Ann McNamara, 'A Legacy of Miracles: Hagiography and Nunneries in Merovingian Gaul', in Julius Kirshner and Suzanne F. Wemple, eds., Women of the Medieval World (Oxford, 1985), 47. For Radegund see also: Jo Ann McNamara and John E. Halbourg, Sainted Women of the Dark Ages (London, 1992), 60-105. Ian Wood, The Merovingian Kingdoms, 450-751 (London and New York, 1994), 183-84.

184 R. L. Cleves, Severus Alexander and the Severan Women (Los Angeles, 1982); E. Kosmetatou, 'The public image of Julia Mamaea. An epigraphic and numismatic enquiry', Latomus 61 
comparing Catherine de Medici to Julia Mamaea, Sens' échevins also likened her to Louis IX's mother, Blanche of Castile, who was one of the most popular secular models of intercessory queenship in pre-modern France. ${ }^{185}$ This thirteenth-century French queen had exercised considerable influence over her son's government (a Bible presented to Louis IX included an image of Blanche of Castile advising him in affairs of state). Blanche was held up as a model of queenship and late medieval writers put a strong emphasis on the mediatory role she had with her son (Christine de Pisan exhorted French queens to follow Blanche's example and intercede with the king). ${ }^{186}$ Municipal councils across the kingdom included references to Blanche in the entries they devised for French queens right through to the sixteenth century. When Claude of France made her entry into Paris on 10 May 1517, the municipal council staged a pageant showing Blanche encouraging Louis IX to receive requests from three petitioners. ${ }^{187}$ One of the reasons why Blanche was such a potent model of French queenship was that motherhood was a source of political power for royal women. ${ }^{188}$ The belief that kings should listen to the advice given by their mothers was ingrained in contemporary notions of good government in pre-modern France. In the greeting speech Charles Ix heard at Narbonne on 3 January 1565 , the consuls exhorted the young king to follow his mother's guidance, making reference to the relationship between the sainted Merovingian queen, Clotilde, and her son the Frankish king, Childebert. ${ }^{189}$ By gaining the support of royal women - and using their special status to draw on contemporary

(2002), 398-414; Clare Rowan, Under Divine Auspices: Divine Ideology and the Visualisation of Imperial Power in the Severan Period (Cambridge, 2012), 219, 222.

185 Vaillancourt, Entrées solennelles, Charles IX, 77.

186 Madeline H. Caviness, 'Anchoress, Abbess, and Queen: Donors and Patrons or Intercessors and Matrons?', in June Hall McCash, ed., The Cultural Patronage of Medieval Women (Athens, 1996), p. 136; Katherine Crawford, Perilous Performances: Gender and Regency in Early Modern France (Cambridge, 2004), 20; Elizabeth McCartney, 'The King's Mother and Royal Prerogative in Early-Sixteenth-Century France', in John Carmi Parsons, ed., Medieval Queenship (Stroud, 1998), 123; A. Poulet, 'Capetian Women and the Regency: The Genesis of a Vocation', in Parsons, Medieval Queenship, 108-10; Karen Pratt, 'Image of the Queen in Old French Literature', in Anne J. Duggan, ed., Queens and Queenship in Medieval Europe (Woodbridge, 1997), 240-41.

187 Kipling, Enter the King, 318; McCartney, 'King's Mother', 129.

188 Indeed, queens often made entries with the dauphin and the other royal children. See, for example, the entry of Eleanor of Austria and the dauphin into Rouen in February 1532: AD Seine-Maritime, AM Rouen A 13, fols. 154v-55r.

189 Vaillancourt, Entrées solennelles, Charles IX, 179. For Clotilde as a royal mother, see: Nira Pancer, Sans peur et sans vergogne: de l'honneur et des femmes aux premiers temps mérovingiens, VI ${ }^{e}-V I I^{e}$ siècles (Paris, 2001), 153, 155; Wood, Merovingian Kingdoms, 136 -37. 
expectations that French monarchs should heed the advice of their mothers - urban governments were employing a further means to encourage the king to follow the advice of these women and act in favour of the town.

The importance of motherhood for the empowerment of royal women was most strongly manifested in the Virgin Mary, who was a popular role model for French queens. As the Bible's most powerful intercessor, urban communities devised ceremonies to seek the Virgin Mary's protection. ${ }^{190}$ Municipal councils also incorporated representations of the Virgin Mary into ceremonial entries as a means to encourage royal women to become their mediator with the king. In particular, urban elites appealed to the queen to use her maternal influence to intercede with the king on their behalf. ${ }^{191}$ Amiens' échevins presented Louise of Savoy with a manuscript that compared her to the Virgin Mary and emphasised the extent of her leverage with the king. ${ }^{192}$ Aside from the Virgin Mary, Esther was the other principal biblical model of intercessory queenship frequently depicted at women's royal entries. ${ }^{193}$ When Mary Tudor made a progress across northern France in 1514, towns such as Beauvais and Montreuil-sur-Mer incorporated representations of Esther into the entries they gave the new queen of France. ${ }^{194}$ As well as comparing Queen Claude to Radegund at Poitiers in 1520 , the consuls used the greeting speech to liken her to Esther. ${ }^{195}$ Nicole Hochner has found that Esther took on a particular significance in France from the late fifteenth century and played a role in

190 John Carmi Parsons, 'Ritual and Symbol in English Medieval Queenship to 1500', in Louisa Olga Fradenburg, ed., Women and Sovereignty (Edinburgh, 1992), 64-65; idem, 'The Pregnant Queen as Counsellor and the Medieval Construction of Motherhood', in John Carmi Parsons and Bonnie Wheeler, eds., Medieval Mothering (New York and London, 1996), 40; Diana Webb, 'Queen and Patron', in Anne Duggan, ed., Queens and Queenship in Medieval Europe (Woodbridge, 1997), 205-20.

191 Cosandey, Reine de France, 175.

192 Anne-Marie Lecoq, 'Le Puy d'Amiens de 1518: la loi du genre en l'art du peintre', Revue de l'Art 38 (1977), 63-74; idem, François I er imaginaire, 333-40; McCartney, 'King's Mother', 129; Potter, Nation State, 58.

193 Nicole Hochner, 'Imagining Esther in Early Modern France', Sixteenth Century Journal 41 (2010), 771, 778-79; Nichole Hochner, 'Pierre Gringore: une satire à la solde du pouvoir?', Fifteenth-Century Studies 26 (2001), 108-11; Pratt, 'Image of the Queen', 236; Kipling, Enter the King, 325-26.

194 Brown, Entrées royales à Paris, 46; Francis Wormald, 'The Solemn Entry of Mary Tudor to Montreuil-sur-Mer in 1514', in J. Conway Davies, ed., Studies Presented to Sir Hilary Jenkinson (London, 1957), 473, 477. See also: Hochner, 'Imagining Esther', 781; Kipling, Enter the King, 326. For Mary and Esther see: Paul Strohm, Hochon's Arrow: The Social Imagination of Fourteenth-Century Texts (Princeton, 1992), 96-99.

195 Rivaud, Entrées princières, 129. 
'the fundamental dilemma between an interventionist monarchy and a decentralized regime.' ${ }^{196}$ Esther had persuaded her husband, King Xerxes (Ahasuerus), to save the Persian Jews from destruction. As Gordon Kipling notes, 'queens were constantly exhorted...to imitate Esther by seeking the well-being of their people, while cities cast themselves in the role as the children of Israel. ${ }^{197}$

The incorporation of powerful models of intercessory queenship into ceremonial entries served more than ornamental purposes: these events had a didactic intent, as urban governments expected royal women to emulate figures such as Esther and act as their agents with the king. Indeed, in their replies to municipal greeting speeches, French queens declared that they would act as brokers for urban communities. When Anne of Brittany made her postcoronation entry into Paris on 19 November 1504, she was greeted outside the city in the customary manner. In response to the prévôt-des-marchands' welcoming speech, Anne thanked the municipal council for the entry and offered to serve as the city's advocate with the king. ${ }^{198}$ Likewise, when Eleanor of Austria entered Compiègne on 15 September 1531, she agreed to the municipal's council's request to have 'the town in good recommendation'. ${ }^{199}$ Moreover, Compiègne's clergy brought a relic of the true cross to the extramural greeting, thus sacralising Eleanor's vow to promote the town's interests. ${ }^{200}$ Although Eleanor proved to have only limited influence with her husband, Francis I, she also maintained influence at the court of her brother, Emperor Charles v. This influence was valuable to Compiègne, as the town lay close to Habsburg lands and had strong economic links with the Low Countries. ${ }^{201}$

These declarations of support went beyond mere courtesy: French queens demonstrated their value as brokers for towns. While Francis I campaigned in Italy in 1515 , his wife, Claude of France, went on a pilgrimage to Sainte-Baume to pray for her husband's success on the battlefield. During this progress, Claude entered Arles, where the consuls greeted her with a lavish reception. Following her entry, the town council brought their requests to the queen, asking her to obtain the confirmation of the town's privileges as well as new economic grants. As soon as her husband returned from Italy, Claude informed

\footnotetext{
196 Hochner, 'Imagining Esther', 758.

197 Kipling, Enter the King, 325-26.

198 Stein, 'Sacre d'Anne de Bretagne', 285.

199 AM Compiègne BB 18 , fol. 10or.

200 Aм Compiègne в в 18, fol. 10or. For this relic, see: Charles Rohault de Fleury, Mémoire sur les instruments de la Passion (Paris, 1870), 129-30.

201 Robert J. Knecht, 'Élénore d'Autriche (1498-1558)', in Michon, Conseillers de François I ${ }^{e r}$, 408-9.
} 
him of the requests she had received at Arles, following which Francis wrote to the consuls stating that he would confirm their existing privileges and give them the additional right to levy taxes on grain sold in the town. The monarch explained that these grants were made 'in favour of the good reception they had made in the town for the lady the queen. ${ }^{202}$ In other words, Francis informed the town council they had won new grants in return for providing his wife with a honourable civic reception. Likewise, when Yolande, duchess of Savoy, travelled to the French court in 1463, she passed through Bourgen-Bresse, where the municipal council greeted her with great ceremony. At the same time as the consuls offered their gifts to the duchess, they also asked her to promote their affairs with her brother, Louis XI. Yolande proved to be an effective broker for Bourg's consuls, who later thanked her for the grants she had obtained from the king to alleviate the damage caused to the town during the wars in Savoy and the Bourbonnais. ${ }^{203}$ These women's relationship with the monarch (daughter, wife or mother) put them in a good position to win grants for the town. In order to utilise this power and influence, town councils staged lavish entries which honoured these women and strengthened their standing in the kingdom, thus encouraging them to return the favour by promoting municipal interests at court.

Urban governments made three principal types of requests to French royal women at their entries. First, they commonly asked them to promote the city's affairs in a general way with the king. During the post-entry banquet held at the royal palace in Paris for Anne of Brittany in 1504, the municipal council presented the queen with a silver statue of a ship (at the cost of 9,0oo livres) and asked her to hold the city in good favour, without making any specific requests. ${ }^{204}$ Likewise, when Catherine de Medici entered Rouen in 1550, the échevins asked her to keep the inhabitants of the town 'in the good grace of her royal spouse'.205 By offering gifts to the queen and binding her to reciprocate in an as yet unspecified way, French towns hoped to develop brokers close to the king who could act for the town when the need arose.

\footnotetext{
202 Ordonnances des rois de France. Règne de François I ${ }^{e r}, 8$ vols (Paris, 1902), i. 337.

203 Aм Bourg-en-Bresse в в 10, fol. 32v.

204 Stein, 'Sacre d'Anne de Bretagne', 300.

205 C'est la deduction du sumptueux ordre plaisantz spectacles et magnifiques theatres, dressés, et exhibes par les citoiens de Rouen... a la sacree Maiesté du Treschristian Roy de France, Henry second leur souverain Seigneur, et à Tresillustre dame, ma Dame Katharine de Medicis... (Rouen, 1551). For the giving of gifts to Catherine, see also: AD Seine-Maritime, AM Rouen A 16, fol. 172v; Beaurepaire, Inventaire sommaire, Rouen, 172.
} 
Second, as queens often travelled with their husbands and typically made their entry on the same day, municipal councils asked these women to encourage the king to ratify existing urban liberties and to speak favourably to him about their petitions for further rights. On the same day as Francis I entered Valence (19 February 1516), the consuls staged an entry for his wife, Claude, and gifted her one hundred écus, in return for which they wanted the queen to recommend the petitions they submitted to the king. These included exemption from the billeting of soldiers, which was a matter of great concern to Valence because troops had started to pour into the region as a result of Francis's recent resumption of the Italian wars. As Claude was a successful broker who had already obtained new privileges for the town, the consuls also used this entry to repay the queen for her past favours. ${ }^{206}$ Similarly, when Henry III and his wife, Louise de Lorraine, entered Orléans on 15 November 1576, the échevins asked the queen to hold the citizens 'in your favour, and grace in all matters, for the confirmation of their privileges and benefits successively granted by the king[s] of France up to the present [day].207 As Orléans had been a bastion of Protestant opposition to the monarchy during the early wars of religion, the citizens wanted to obtain the mediatory services of the queen to keep the city in the king's favour and obtain the confirmation of its liberties. ${ }^{208}$ Although Louise's inability to provide a royal heir would eventually lead to the diminishing of her influence at court, she had been married to Henry III for less than two years at the time of the Orléans' entry and her infertility had not yet impaired her intercessory powers.

The final type of request that urban governments brought to the monarch's female relatives related to the specific political or economic aims they wanted royal women to promote with the king and his ministers when they returned to court. When Margaret of Valois, sister of Henry III, entered Saintes in March 1582, the échevin Charles Farnoulx asked her to persuade her brother to discharge the town from the gabelle and other subsidies, which she promised to do. ${ }^{209}$ Likewise, when Eleanor of Austria entered Châlons-en-Champagne in July 1535 , the municipal council asked her to obtain the curtailment of the powers the bailli of Vermandois held over the city, with the concomitant restoration of the town council's authority over the customs of the city. ${ }^{210}$

\footnotetext{
206 Aм Valence в в 4, fols. 95r-96r.

207 Mulryne, Watanabe-O'Kelly and Shewring, Europa Triumphans, i. 184-201.

208 Jacqueline Boucher, Deux épouses et reines à la fin du XVIe siècle: Louise de Lorraine et Marguerite de France (Saint-Étienne, 1995), 112-13.

209 Louis Audiat, Entrées royales de Saintes (Paris, 1875), 19.

210 AC Châlons-en-Champagne B B 8, fol. 25 r.
} 
The efforts of the baillis of Vermandois to impose their power over Châlons' other judicial authorities from the late fifteenth century had led to an erosion of the juridical privileges held by the town council. ${ }^{211}$ The municipal council hoped to enlist Eleanor to persuade her husband to have his officials respect traditional municipal rights regarding the provision of justice.

Female power was not restricted to mediation with the king: some royal women had the authority to grant urban requests without having to first speak to the king. When Catherine de Medici visited Agen in 1578, she made a number of rulings relating to security provisions. ${ }^{212}$ As Catherine was one of the most powerful people in France, municipal governments sought to present her with petitions during her progresses. When the rulers of the small Gascon town of Auch learnt that Catherine was travelling from Agen to Toulouse, they decided to send a delegation to attend the entry at Toulouse and offer her their petitions. ${ }^{213}$ Between the reigns of Charles VIII and Charles IX, France had a succession of female regents. The entries of Anne de Beaujeu, Louise of Savoy and Catherine de Medici were particularly important for urban leaders because these women were invested with substantial political power. When Francis conferred the regency on his mother, Louise, in August 1525, he gave her the right to receive requests and petitions. ${ }^{214}$ Likewise, when Henry II appointed his wife, Catherine de Medici, regent on 15 August 1553, he ruled that his subjects were to submit their requests to the queen and the royal council as if they were submitting them to him. ${ }^{215}$ Even beyond their tenure as regent, these women wielded considerable political influence. With the ascension of her son to the throne in January 1515, Louise of Savoy became one of the most powerful people in France. ${ }^{216}$ Within a month of his sacre, Francis had raised his mother's county of Angoulême to the status of a duchy, appointed her half-brother Charles to the governorship of Normandy and made her household favourite, Antoine Duprat, chancellor of France. Moreover, as Robert Knecht notes, 'Francis had the reputation of being ruled by his mother.217

211 Barthélémy, Histoire de Chalons-sur-Marne, $5^{2-3}$.

212 Auguste, Inventaire sommaire, Agen, (Paris, 1884), 31.

213 In the end, bad weather prompted the royal party to change its itinerary and visit Auch, thus sparing the consuls the expense of the journey: АС Auch в в 5 , fol. $518 \mathrm{v}$.

214 McCartney, 'King's Mother', 131.

215 F.-A. Isambert et al, eds., Recueil général des anciennes lois françaises, depuis l'an 420 jusqu'à la révolution de 1789, 29 vols (Paris, 1833), xiii. 341. See also: Crawford, Perilous Performances, 22.

216 Robert Knecht, 'Louise de Savoie (1476-1531)', in Michon, Conseillers de François I I r, 176.

217 Robert Knecht, '“Our Trinity!": Francis I, Louise of Savoy and Marguerite d'Angouleme', in Munns and Richards, Gender, Power and Privilege, 78. 
Given Louise's influence over her son, urban governments used ceremonial entries to offer her gifts and bind her to reciprocate on their behalf with her son. Aware of her power, municipal governments attempted to recruit Louise as a broker as soon as her son's ascension appeared imminent. When Louis XII lay dying in November 1514, the Parisians municipal council provided a lavish entry for Louise, offering her items of silverware and asking her 'to have the town and its inhabitants in good recommendation.218 The Parisians capitalized on all possible opportunities throughout her son's reign to sustain their relationship with Louise. For example, the municipal council used Claude of France's coronation entry into Paris in 1517 as a pretext to offer Louise further expensive gifts of silverware. According to the municipal deliberations, the gifts were made to the queen mother because she 'has the government of the kingdom. The city council hoped to use this present to secure Louise's 'benevolence and put this town of Paris and its inhabitants in her grace and love.'.219 The échevins hoped that their gift 'would be of great profit to the town in various matters that could occur... because the honour and pleasure made to the mother returns to the son'.220 The rulers of Paris maintained their relationship with this highly influential royal woman right through to the end of her life. Three months before her death on 22 September 1531, Louise entered Paris at the side of her son's second wife, Eleanor of Austria. As with the entry of Claude in 1517, the Parisians decided to give Louise a gift to have the business of the town in good recommendation.' ${ }^{221}$ While many of the institutions of royal government (including the parlements of Paris and Languedoc) had challenged Louise's power, particularly during her second term as regent (1525-26), the Parisian municipal council provided her with ceremonies that honoured her status and recognised the legitimacy of her political authority, in return for which Louise used her power to benefit the city's rulers. ${ }^{22}$

\footnotetext{
218 Bonnardot, Registres Paris, 1499-1526, 277.

219 Bonnardot, Registres Paris, 1499-1526, 239-40.

220 Bonnardot, Registres Paris, 1499-1526, 240.

221 Tuetey, Registres Paris, 1527-1539, 117. When Louise entered Lyon in 1516 in the entourage of Queen Claude, the consuls presented her with gifts and 'recommended the business of the town to her'. Accepting the presents, Louise offered to help the city in any way she could: AM Lyon cc 666, fol. 47r. For this entry, see also: E. Baux and V.-L. Bourilly, 'François Ier à Lyon en 1516', Revue d'histoire de Lyon 12 (1913), 116-45.

222 For example, in February 1525 Louise used her powers as regent to grant Paris an octroi on all the fish and salt sold in the city for six years: Bonnardot, Registres Paris, 1499-1526, 277. For challenges to Louise's authority, see: Brink, 'Louise de Savoie', 15-25; Roger Doucet, Étude sur le Gouvernement de François I ${ }^{\text {er }}$ dans ses rapports avec le Parlement de Paris, 1525-1527 (Paris, 1926).
} 
The staging of a royal entry gave municipal councils an opportunity to contact a range of influential royal women, both French and foreign. Indeed, urban governments granted entries to women who could not expect one by right as a way to gain their support. In 1548, Anna d'Este, duchess of Ferrara and daughter of Renée of France, entered Paris. In the greeting speech, the prévôtdes-marchands told the princess that while it was not customary to accord an entry to anyone but the king, queen, dauphin and princes, the city was affording her this honour because she was a 'princess descended from the Crown and house of France'. Although Anne was the granddaughter of Louis XII through the maternal line, she could not claim an entry by right; it was an honour conferred on her by the city. By preparing an entry for Anne, the Parisians accorded her a great mark of respect which they used to play upon the princess's vanities. As Penny Richards has noted, Anne had a strong 'sense of status - not as a Guise or Nemours, but more grandly as a member of the royal family of France. ${ }^{223}$ In return for granting an entry which promoted Anne's status in the kingdom, the Parisians asked her 'to keep us in your good grace and to recommend the business of the town towards his majesty the king.'. ${ }^{224}$ The speech hit its target and the princess thanked them 'for the honour that you have made me, [which is] so great that it does not belong to me' and assured the échevins she would use her power and influence on behalf of the city. ${ }^{225}$

While obtaining Anne's promise to act on their behalf was undoubtedly useful for Paris's échevins, of greater importance was the favour they won with Francis of Guise, who was due to marry Anne in Paris. As a successful military commander who was popular at court, Francis was one of the kingdom's leading men. The Guise used Francis's marriage to Anne d'Este to extend their influence in France, and the Parisians' efforts to prepare a royal reception for the princess increased the family's honour. ${ }^{26}$ Once Anne had replied to the city's formal greeting, Francis 'kissed numerous times' the prévôt des marchands, saying that he was indebted to the municipal council for the honour that your have done to my children and me today. I give thanks to God and men for this, and assure you that I will never spare pleasing the town, whether

223 Penny Richards, 'The Guise women: Politics, war and peace', in Munns and Richards, Gender, Power and Privilege, 167; Jessica Munns and Penny Richards, 'Exploiting and Destabilizing Gender Roles: Anne d'Este', French History 6 (1992), 208, 212.

224 Guérin, Registres Paris, 1539-1552, 140-41.

225 Guérin, Registres Paris, 1539-1552, 139.

226 Richards, 'The Guise Women', 165; Stuart Carroll, Martyrs and Murderers: The Guise Family and the Making of Europe (Oxford, 2009), 61. 
in general or in particular.227 In other words, Francis offered to promote a good impression of the city at court and act as their broker for specific matters. The Guise were fully aware of the political power that could be gained from ceremonial entries $^{228}$ and this unusual display of heightened emotion was a mark of the extent of Francis's gratitude to the Parisian municipal council for the honour it had done him by according an entry to his betrothed. By means of this entry the échevins successfully created a relationship with Francis of Guise, which grew stronger throughout the sixteenth century. ${ }^{229}$

Royal entries also gave urban governments opportunities to develop links with members of Valois women's households, such as the three hundred noblewomen who accompanied Catherine de Medici when she toured the kingdom in $1564-65 .{ }^{230}$ Close relationships often developed between royal women and the members of their households, who typically travelled separately from the king. ${ }^{231}$ Municipal councils gave gifts to the influential men and women who accompanied the queen in order to encourage them to act as their agents. In 1464, Nevers gave a silver water jug to one Isabeau de la Leck, the principal lady in the household of Jacqueline d'Ailly, countess of Nevers, 'so that she passes the needs of the town and region to Madame [Jacqueline], and from one to another to engage Monsieur the count to take stock of it. ${ }^{232}$ In other words, the échevins expected that the provision of a gift to an influential member of the countess's entourage would spark off a series of events that would encourage John, count of Nevers, to intervene of behalf of the town. The potential consequences of such actions were magnified when these gifts were provided to leading women in the queen's entourage. When Isabella of Bavaria entered Paris in 1389, the échevins offered an expensive gift to Valentina Visconti, duchess of Orléans, who thanked the town council and

\footnotetext{
227 Guérin, Registres Paris, 1539-1552, 139.

228 Richards, 'The Guise Women', 166.

229 Barbara Diefendorf, Beneath the Cross: Catholics and Huguenots in Sixteenth Century Paris (Oxford, 1991), 62-63; Stuart Carroll, 'The Guise affinity and popular protest during the Wars of Religion', French History 9 (1995), 125-52.

230 Vaillancourt, Entrées solennelles, Charles $I X, 56$.

231 Cordula Nolte, 'Gendering Princely Dynasties: Some Notes on Family Structure, Social Networks, and Communication at the Courts of the Margaves of Brandernburg-Ansbach around 1500', in Pauline Stafford and Anneke B. Mulder-Bakker, eds., Gendering the Middle Ages (Oxford, 2001), 185 .

232 C. A. Parmentier, Archives de Nevers, ou inventaire historique des titres de la ville, 2 vols (Paris, 1842), i. 168. For Isabeau de la Leck, see: Corneille Stroobant, Histoire de la commune de Feluy (Brussels, 1858), 72-78.
} 
remarked that 'the good city of Paris had profited from it.'. ${ }^{233}$ The duchess made it clear to Paris's leaders that they stood to benefit from having made this gift because they had obtained her favour and influence at court. As the wife of Louis, duke of Orléans, who was the king's brother and one of the most powerful men in the kingdom, Paris could hope to profit from Valentina's patronage. Furthermore, gift giving allowed urban governments to establish networks with people they anticipated to be future power brokers at court. When Anne of Beaujeu entered Amiens in 1483, the échevins offered gifts to Margaret of Austria, then betrothed to Charles VIII, whom they expected to become queen of France. ${ }^{234}$ In addition, the wives of rulers also travelled with influential male officials. When the duchess of Burgundy entered Amiens in 1448, the échevins gave Antoine de Crö̈ (one of the most powerful members of Philip the Good's household) a gift of forty écus to repay him for having promoted the city's interests with the duke and duchess of Burgundy. Moreover, Amiens' échevins used gift giving to retain Croÿ's services and 'also to speak with him about having exemption from the taille'. ${ }^{235}$ As the members of elite women's households included ambitious men seeking advancement in the administrations of their husbands, urban governments used entries to attach themselves to these officials at an early stage of their career. ${ }^{236}$ In short, ceremonial entries provided a further way for urban governments to access the female brokers who lay at the centre of government, obtaining their assistance in return for staging entries that augmented their authority and supported their right to wield political power.

The ability to travel with the king benefited the members of his household, who received gifts from town councils during a royal entry. The provision of these payments increased the king's prestige because he was seen as a source of wealth and prosperity for those around him. Contact with the members of royal households also provided municipal councils with opportunities to gain access to those in power, which was essential to secure the granting of petitions. In particular, urban administrations offered gifts and payments to

\footnotetext{
233 Buchon, Chroniques de Froissart, xii. 24-25.

234 AM Amiens BB 14, fol. gov.

235 Aм Amiens вв 6, fols. 124r, 124v. For the powers held by Antoine de Crö̈, see: Richard Vaughan, Philip the Good: The Apogee of Burgundy (Woodbridge, 1970), 140-41.

236 For men using positions in elite's women's household to promote their careers, see: Ruth Kleinman, 'Social Dynamics of the French Court: The Household of Anne of Austria', French Historical Studies 16 (1990), 517-21; Sharon Kettering, 'The Household Service of Early Modern French Noblewomen', French Historical Studies 20 (1992), 56-57.
} 
members of the royal household who had influence with the king or who controlled access to his chambers. For instance, when Narbonne's consuls learnt that Charles IX intended to enter the town, they set aside 1,00o écus specifically to put towards paying court officials to promote their business with the king. ${ }^{237}$

The first stage in obtaining the approval of urban petitions was winning friends at court. As well as offering municipal councils an opportunity to recruit new brokers, urban rulers also used entries to repay dignitaries for efforts they had already taken on their behalf. There were some individuals who by virtue of their position and standing with the king were particularly valuable for urban governments, most notably the members of the royal council. One of the fundamental characteristics of the royal council was that it was inseparable from the person of the king. The council accompanied the king wherever he travelled, and its members were amongst the few people who were permitted to lodge with the king on a progress. Furthermore, the members of the royal council were permitted entry to the monarch's most personal spaces, particularly the cabinet. ${ }^{238}$ Their presence next to the monarch reminds us that while Paris was administrative capital of the kingdom, executive power was peripatetic.

As we saw, municipal councils offered their petitions to the monarch during the post entry gift giving ceremony. These requests were given orally and in return the king gave a verbal confirmation of their requests. Nonetheless, gaining the king's approval of petitions was not enough to ensure that these liberties were implemented. On the contrary, the process of winning grants was considerably more complex than the straightforward dialogue between the king and civic elite during the gift-giving ceremony. While kings approved urban petitions, there was no guarantee the grants would be implemented. Essentially, the king's verbal consent gave the municipal council permission to pursue the matter further with the members of his administration, represented especially by the royal secretaries. As the king did not read urban requests, his secretaries interpreted them for him. By the late fifteenth century, the secretaries held the real power to grant requests, reflecting their rise to prominence in the royal administration. While their role is often overlooked, in many ways the royal secretaries were more important than the king in the granting of urban liberties. Although the royal secretaries were often drawn from the upper bourgeoisie, their loyalty was to the Crown and their privileged social status was dependent on service to the monarch. The secretaries' increasing

237 AM Narbonne B B 1, fol. 307v.

238 Michon, 'Conseils et conseillers', 31. 
role in the allocation of urban liberties is apparent in the scale of the payments they received at royal entries. While the king posed as the worthy successor of Louis IX, who was open to receive petitions from all (and powerful enough to grant them), in reality the monarch's role in according grants was minimal and by the late fifteenth century towns found that they had to deal more fully with royal officials than ever before.

The king's female relatives were amongst the most influential people in the kingdom. Although the wider culture of the age was undoubtedly misogynistic and patriarchal, royal women played an important role in the affairs of the kingdom. These women were crucial to the government of France, and they exerted their power with the king through both formal and informal means. Although Valois royal women had lost some of the extensive powers accorded to their Capetian, Carolingian and Merovingian predecessors, they nonetheless remained very influential in the governance of the kingdom. During the fifteenth and sixteenth centuries, a combination of mental illness, civil and foreign wars, as well as royal minorities, placed a succession of Valois women at the centre of power, including Isabella of Bavaria, Anne de Beaujeu, Louise of Savoy and Catherine de Medici. Urban governments used ceremonial entries to harness the power and influence these women had as representatives of the king. As we shall see in the following chapter, urban elites deployed these same tactics when devising entries for provincial governors. 